\title{
Fen Bilimleri Öğretmenlerinin FeTeMM ile İlgili Görüşlerinin İncelenmesi*
}

\section{Zeynel BOYNUKARA**, Aslı Nur DENIZ*** ve Mustafa TÜYSÜZ ${ }^{* * * *}$}

Öz: Araştırmanın amacı fen bilgisi öğretmenlerinin FeTeMM eğitimi hakkındaki bilgi ve görüşlerinin araştırılması olarak belirlenmiştir. Çalışma nitel araştırma yöntemlerinden fenomenoloji deseni ile gerçekleştirilmiştir. Araştırmanın örneklemini Van İli Merkez ilçelerinde (Tuşba, İpekyolu ve Edremit) görev yapan 50 gönüllü Fen Bilimleri öğretmeni oluşturmuşstur. Araştırmada veriler, açık uçlu anket, yarı yapılandırılmış görüşme ve gözlem tekniği kullanılarak toplanmıştır. Verilerin analizi nitel analiz yöntemlerinden içerik analizi ile değerlendirilmiştir. Araştırma sonrasında bulgular kendilerine ait kategoriler altında kodlanarak belirtilmiştir. Çalışma sonucunda Fen Bilimleri öğretmenlerinin FeTeMM ile ilgili yeterli alan bilgisine sahip olmadıkları belirlenmiştir. Ayrıca öğretmenlerin FeTeMM eğitimini sınıf ortamlarında uygulamada zorluklar yaşadıkları gözlenmiştir. FeTeMM eğitiminde öğretim yöntem/stratejileri kullanmada ve öğrencilerin değerlendirilmesinde Fen Bilimleri öğretmenlerinin çoğunun yeterli olmadıkları bulunmuştur. Çalışma ile ilgili öneriler tartışılmıştır.

Anahtar Kelimeler: Fen bilimleri dersi, Fen bilimleri öğretmenleri, FeTeMM, fenomenoloji

\section{Investigation of the Views of Science Teachers on STEM}

\begin{abstract}
The aim of the research was to examine science teachers' knowledge and opinions about STEM education. The research was carried out with the phenomenology as the type of qualitative research methods. The sample of the study consisted of 50 voluntary science

\footnotetext{
*Bu çalışma "Fen bilimleri öğretmenlerinin FeTeMM ve Sosyobilimsel Konular ile ilgili görüşlerinin incelenmesi"' başlıklı yüksek lisans tezinin bir bölümünden üretilmiştir (Zeynel BOYNUKARA, Mustafa TÜYSÜZ, 22.03.2019).

**Dr. Öğr. Üyesi Van Yüzüncü Yıl Üniversitesi, Eğitim Fakültesi, Fen Bilgisi Eğitimi Anabilim Dalı, email: bzeynel@yahoo.com Orcid No: 0000-0002-0440-6281

${ }^{* * *}$ Öğretmen,Milli Eğitim Bakanlı̆̆

**** Dr. Öğr. Üyesi Van Yüzüncü Yıl Üniversitesi, Eğitim Fakültesi, Fen Bilgisi Eğitimi Anabilim Dalı, email: mustafa.tysz@ yahoo.com Orcid No: 0000-0003-1277-6669
} 
teachers working in the central districts of Van Province (namely, Tusba, İpekyolu, and Edremit). In the research, the data were collected by using an open-ended questionnaire (including seven STEM questions), semi-structured interviews, and classroom observations. The data were analyzed by content analysis from qualitative analysis methods. The findings were coded under the identified categories. As a result of the study, it was determined that science teachers did not have sufficient subject matter knowledge regarding STEM subjects. In addition, it was observed that they had difficulties in applying STEM in class. Especially it was found that most of the science teachers were not adequate in the use of teaching methods/strategies and the evaluation of their students in STEM education. The suggestions related to the study were discussed.

Keywords: Science, Science Teachers, STEM, Phenomenology.

\section{Giriş}

İçinde bulunduğumuz yüzyıl birçok değişim ve gelişimi beraberinde getirmektedir. Bu değişim ve gelişimlere hızlı bir şekilde uyum sağlayabilecek bireylerin yetiştirilmesi gelişmiş ve gelişmekte olan ülkelerin en büyük eğitim politikaları arasında yer almaktadır. Bu eğitim politikaları doğrultusunda bireylere 21. Yüzyılın gerektirdiği özellikleri kazandırmak için bilim insanları birçok eğitim yaklaşımı üzerinde çalışmaktadır. Bu eğitim yaklaşımlarımdan biri de Fen, Teknoloji, Mühendislik, Matematik disiplinlerinin birbirleriyle bütünleştirildiği “FeTeMM' eğitimidir (International Technology and Engineering Educators Association [ITEEA], 2009). Son yıllarda gittikçe popülaritesi artan bu eğitim yaklaşımı başta ABD olmak üzere birçok ülkede FeTeMM'i devlet politikası haline getirerek, öğrencilerde olumlu tutumlar geliştirmeyi ve kariyer bilincine sahip bireyler yetiştirmeyi amaçlamaktadır (Akgündüz \& diğ., 2015; National Research Council, 2011). Bu politikalar kapsamında FeTeMM eğitiminin iki asıl amacının olduğu görülmektedir. Bunlardan birincisi; FeTeMM ile ilgili yükseköğretim seviyesinde meslek tercihinde bulunacak olan öğrenci sayısını üst seviyeye çıkarmak, ikinci amaç ise öğrencilerin FeTeMM ile ilgili hazırbulunuşluk seviyelerini arttırarak, yaşadıkları çevrede karşılaştıkları problemlerin çözümüne odaklanabilmelerini sağlamaktır (Thomasian, 2011). Bu temel amaçlar doğrultusunda birçok bilim insanı FeTeMM eğitimi ile ilgili çeşitli tanımlar ortaya koymuşlardır. Genel olarak FeTeMM eğitimi birbirinden farklı görünen Fen, Teknoloji, Mühendislik ve Matematik disiplinlerinin bir araya getirilerek ortak bir paydada buluşturulması şeklinde tanımlanmıştır (Akgündüz, Ertepınar, Ger, Kaplan Sayı \& Türk, 2015; 
Bybee, 2010; Çorlu, Capraro \& Capraro, 2014; National Research Council [NRC], 2011; Riechert \& Post, 2010). Nitelikli ve çok yönlü bireyler yetiştirmede FeTeMM eğitimine düşen rol büyüktür (Bybee, 2010; Sanders, 2009). FeTeMM eğitiminde bireyler birden fazla alanı bağlantılı olarak düşündüklerinden dolayı farklı özellikler kazanmış ya da var olan bazı özelliklerini açığa çıkarmış olacaklardır. Yani FeTeMM eğitimi ile öğrencilerin içinde bulunduğumuz çağın özellikleri olan problem çözebilme, teknolojinin doğasını anlayabilme, , sistematik düşünebilme, iletişim becerileri gelişmiş, yaratıcı ve özgüvenli bireyler olma gibi özellikleri kazanmaları hedeflenmektedir (Bybee, 2010; Denson, 2011; Jonassen, 2011; Morrison, 2006; Niess, 2005). Bununla birlikte, bu eğitim yaklaşımı, öğrencilerin günlük yaşamda karşılaştıkları ya da gelecekte karşılaşabilecekleri problemlere çözümcül yaklaşabilmelerini, öğrendikleri bilgileri farklı disiplinler ile entegre ederek kullanabilmelerini, bilgiyi organize ederek sunabilmelerinihedeflemektedir (Akyıldız, 2014; Capraro \& Slough, 2008; Dugger, 2010; Morrison, 2006; Yıldırım \& Altun, 2015; Yıldırım \& Selvi, 2016). Böylece bu eğitim problemlere birden fazla açıdan bakma, bilgiyi başka bir bilgiye transfer edebilme, aktif öğrenme, iletişim kurma, yaratıcı ve eleştirel düşünme ve disiplinler arası kavramsal entegrasyon gibi becerilerin gelişimlerine katkı sağlamayı hedeflemektedir (Berlin \& White, 2001; Bransford, Brown, \& Cocking, 2000; Meyrick, 2011; Sanders, 2008; Wai, Lubinski \& Benbow, 2010; Yıldırım \& Altun, 2015). FeTeMM eğitimi almış olan bireylerin öz güveni yüksek, mantıklı düşünen, yenilikçi, fen ve teknoloji okuryazarı olmaları dışında farklı bilim alanlarında kariyer yapabilecek yeterliliğe sahip olmaları da beklenmektedir (Bybee, 2010; Morrison, 2006; National Research Council 2012).

Alanyazın incelendiğinde FeTeMM'in içinde bulundurduğu disiplinlerin bir bütün olarak ele alınmasının öğrencilerin tutum, ilgi, doğru mesleğe yönelim gibi eğilimleri üzerinde pozitif yönde etki ettiği görülmektedir (Baran, Canbazoğlu Bilici, Mesutoğlu, 2015; Biçer vd, 2015; Gencer, 2015; Guzey, Harwell \& Moore, 2014; Yıldırım \& Selvi, 2017). FeTeMM disiplinleri arasında kurulan bağın öğrenciler tarafından anlaşılması ve öğrencilerin çalışma alanlarına aktarabilmesi, FeTeMM disiplinlerinin bir arada kullanmaları açısından önem taşımaktadır (Knezek vd, 2013). Başka bir araştırmada ise, Doppelt ve arkadaşları (2008), elektrikli alarm sistemi tasarlamaya yönelik çalışma yaparak FeTeMM'in öğrencilerin öğrenme düzeylerine etkisini incelemiş ve çalışma sonucunda; FeTeMM'in öğrencilerin bilgi düzeylerini arttırdığı, öğrencilerin fen konularında ilgi ve başarılarının artmasında önemli bir role sahip olduğu sonucuna varılmıştır. Yine, Baran ve arkadaşları (2015), FeTeMM spotu tasarlama 
etkinliği çalışmalarında 6. sınıf öğrencilerine FeTeMM spotu tasarlatmışlar ve çalışma sonucunda FeTeMM spotu tasarlamanın öğrencilerin teknoloji ve bilgisayar dersine olan ilgi, bilgi ve becerilerini geliştirdiği belirlemiştir. Şahin ve arkadaşları (2014) ise yaptıkları çalışmada FeTeMM içerikli ders dışı etkinlik özelliklerini inceleyerek, FeTeMM eğitiminin 21. yüzyıl becerilerini geliştireceği ve iş birliği içinde çalışmaya olanak sağlayarak araştırmalara olumlu yönde katkı sağlayabileceği sonucuna ulaşılmıştır. Buna eş değer olarak FeTeMM ile ilgili yapılan diğer çalışmalarda ise, FeTeMM eğitiminin öğrencilerin problem çözme becerilerini geliştirerek daha yaratıcı düşünmelerini ve bir arada çalışmalar yaparak yeteneklerini geliştirmelerini sağladığı sonucuna ulaşılmıştır (Akaygun \& Aslan-Tutak 2016; Bybee, 2010; Jerald, 2009; Levy \& Murnane, 2004; Schmidt, 2011; Tyson, Lee, Borman, \& Hanson, 2007; Wagner, 2008).

FeTeMM eğitiminin ülkemizde kullanılması ise çok yakın bir tarihe dayanmaktadır. Türkiye Cumhuriyeti Eğitim sistemi 2004 yılında başlayan kademeli bir öğretim programı ile yenilenme sürecine girmiş ve ilköğretimden üniversiteye kadar bütün öğretim programlarında yenilikler yapılmıştır. 2005 yılında Fen Bilgisi öğretim programına teknoloji kavramı da eklenerek dersin yeni adı Fen ve Teknoloji olarak değiştirilmiş ve haftalık ders süresi üç saatten dört saate çıkartılmıştır (MEB, 2005). Değişen Fen Bilimleri eğitim programı ile birlikte; bireylerin konuları öğrenmeye istekli, girişimci, gözlem yapabilen, yeni geliştirilen teknolojilere çabuk adapte olan ve bu teknolojileri kullanabilen, keşfeden, veri toplayabilen, sorunlara çözüm üretebilen özelliklere sahip olmaları amaçlanmıştır (MEB, 2000, 2005a, 2005b, 2013). Bu durumun temel sebebi olarak Fen Bilimlerinin, ülkelerin kültürel, ekonomik ve sosyal açıdan gelişmesinde ve ilerlemesinde önemli bir yere sahip olması gösterilebilir. Ülkemizde de kültürel, sosyal ve ekonomik yönden ilerlemeler kaydedebilmek için fen bilimlerine gereken önem verilmeye çalışılmaktadır. Nitelikli insanların yetişmesine ihtiyaç duyulan ülkemizde ilkokul ve ortaokul düzeyindeki çocukların öğrenim gördüğü kurumlarda fen öğretimi büyük öneme sahiptir (Korkmaz, 2002). Bu kapsamda, farklı disiplinleri içerisinde barındıran fen bilimlerinin amacına uygun bir şekilde öğretilmesi ayrıca önemli görülmektedir. $\mathrm{Bu}$ bakımdan farklı disiplinleri bütünleştiren bir eğitim anlayışını temel alan FeTeMM yaklaşımının fen bilimleri dersinin öğretilmesi için uygun olduğu düşünülmektedir. $\mathrm{Bu}$ bağlamda, ülkemizde 2017 yılında yapılan düzenleme ile FeTeMM, Fen Bilimleri Dersi Öğretim Programına 'Uygulamalı Bilim' olarak dahil edilmiştir. Bu öğrenme alanı kapsamında fen bilimleri ders kitabına 'Fen ve Mühendislik Uygulamaları' ünitesi olarak ekleme yapılmıştır 
(MEB, 2017). Yapılan bu değişikliklerle birlikte, FeTeMM eğitiminin daha verimli olabileceği yaklaşım ve öğretim yöntemleri de güncellemeler dâhilinde programa eklenmiştir.

$\mathrm{Bu}$ bağlamda FeTeMM eğitiminin amacına uygun şekilde kullanılmasının ve öğrencilere yeterlik düzeyi yüksek eğitim verilmesinin en önemli ön koşullarından birisi öğretmen eğitimidir. FeTeMM eğitiminin eğitim ortamlarına dâhil edilme amacına uygun bir şekilde uygulanabilmesi için, öğretmenlerin bu konuda belli bir deneyim ve beceriye sahip olmaları gerekmektedir (Çorlu \& diğ., 2014). FeTeMM eğitiminde öğretmenler yeniliklere açık, bilimsel araştırmalar yapmaya hevesli, problem çözme becerilerine sahip, iş birliği içinde çalışabilen ve sabırlı bir birey olma gibi özellikler göstermelidirler (Tezel ve Yaman, 2017). Uygulanmakta olan fen bilimleri öğretim programında öğretmenler bu özellikleri göstererek; mühendislik tasarım sürecini kullanabilmeli ve mühendislik alanını diğer alanlarla birleştirerek öğrenmelerin gerçekleşmesini sağlayabilmelidir (Burrows, Breiner, Keiner \& Behm, 2014; Carmel, Ward, \& Cooper, 2017). Fakat öğretmenlerin gerek teorik gerekse pratik olarak FeTeMM eğitimi konusunda yeterli olmadıkları ulusal ve uluslararası FeTeMM raporlarında belirtilmektedir (Akgündüz \& diğ., 2015; PISA, 2016; Sanders, 2009). Alan yazında FeTeMM eğitimi ile ilgili olarak öğretmenlerle yapılan çalışmalara bakıldığında, öğretmenlerin disiplinlerarası yaklaşımı kullanarak öğretim yapmakta zorlandıkları ve bunun da temel sebebi olarak yeterli alan bilgisine sahip olmamalarını gerekçe olarak sundukları görülmüştür (Stinson, Harkness, Meyer \& Stallworth, 2009). Örneğin; fen bilimleri öğretmen adayları ile yapılan bir araştırmada, fen bilimleri öğretmenlerinden matematik alanında eğitim alan adayların almış oldukları matematik bilgilerini fen deneylerine entegre etmede zorluk yaşadıkları belirlenmiştir (Aydın \& Delice, 2007). Başka bir çalışmada ise, Tüysüz ve arkadaşları (2018) yaptıkları çalışmada fen bilimleri öğretmenleri ve fen bilimleri öğretmen adaylarının biyoloji, fizik ve kimya disiplinlerini birbirlerine entegre etmede yetersiz alan bilgilerine sahip olduklarını bulmuşlardır. Ayrıca, kavramsal entegrasyonun uygulanmasında katılımcıların büyük bir çoğunluğunun güçlük yaşadıkları belirlenmiştir. Son olarak öğretmenler kavramsal entegrasyonu kullanırken, herhangi bir öğretim yöntem ve ölçme değerlendirme metodu kullandıklarına yönelik bir görüş belirtmemişlerdir. Bu bakımdan içinde bulunduğumuz çağda beklenilen özelliklere sahip bireyler yetiştirmede ve yenilenen programın uygulayıcısı olan öğretmenlerin FeTeMM eğitimi ile ilgili bilgilerine yönelik var olan durumlarının belirlenmesi ileride yapılacak çalışmaların şekillenmesi için önemli görülmektedir. Bu kapsamda FeTeMM eğitiminin odak noktasında olan öğretmenlerle ilgili daha fazla çalışma yapılmasına ihtiyaç 
vardır. Buna yönelik olarak araştırmada fen bilimleri öğretmenlerinin FeTeMM eğitimine yönelik bilgi ve uygulamalarına yönelik görüşleri araştırılmıştır. Belirlenen bu amaç kapsamında çalışmanın problem cümlesi "Fen bilimleri öğretmenlerinin Fen, Teknoloji, Mühendislik ve Matematik (FeTeMM) eğitimine yönelik
a) alan bilgileri,
b) farkındalıkları,
c) zorluk durumları,
d) kullandıkları öğretim yöntem/stratejileri,
e) katkıs1
f) kullandıkları ölçme değerlendirme yöntemleri

hakkındaki görüşleri nelerdir?” olarak belirlenmiştir.

\section{Yöntem}

\section{Araştırmanın Deseni}

$\mathrm{Bu}$ çalışmada nitel araştırma yöntemlerinden biri olan fenomenoloji kullanılmıştır. Fenomenoloji; deneyim sahibi olduğumuz fakat bu deneyimlerimiz üzerinde düşünmediğimiz olgularımızı ayrıntılı bir şekilde inceleyen nitel araştırma desenidir (Creswell, 2009; Frankel \& Wallen, 2000; Yıldırım \& Şimşek, 2013). Buradan hareketle, bu araştırmada da fen bilimleri öğretmenlerinin daha öncesinde aslında kendilerinde var olan fakat farkında olmadıkları FeTeMM eğitimi ile ilgili düşünce ve bilgileri derinlemesine araştırılmıştır.

\section{Çalışma Grubu}

Çalışmaya katılacak öğretmenler belirlenirken amaçlı örnekleme yöntemlerinden maksimum çeşitlilik örnekleme yöntemi kullanılmıştır. Maksimum çeşitlilik yönteminin seçilerek uygulanmasının amacı küçük bir örneklem grubu oluşturmak ve bu örneklem gurubunda çalışılan problemlere taraf olabilecek öğretmenlerin çeşitliliğini maksimum derecede yansıtmaktır (Yıldırım \& Şimşek, 2008). Ayrıca çalışma grubunun çeşitli yönleriyle (cinsiyet, hizmet yılı, görev yaptıkları okulların türleri ve yaş) ele alınarak, ayrıntılı bir şekilde incelenmesi sonucu bilgiye ulaşılmakta ve örneklem çeşitlemesi ile geniş kitleyi kapsaması amaçlanmaktadır (Creswell, 2007). Buradan hareketle, araştırmaya gönüllülük esasına uygun olarak 50 fen bilimleri öğretmeni katılmıştır. Çalışmaya farklı okullarda görev yapmakta olan 28 kadın, 22 erkek fen bilimleri öğretmenleri katılmıştır. Öğretmenlerin yaşları 23 ile 40 arasında değişirken, meslek deneyimleri en az 1 yıl ve en fazla 15 yıl arasındadır. Bulgular 
bölümünde öğretmenlerin açık uçlu sorulara verdiği cevaplar sunulurken, FBÖ-1, FBÖ2, ,.,FBÖ-50 şeklinde kodlanmıştır. Sınıf seviyesi olarak fen bilimleri dersine giren 5.,6.,7.ve 8.sınıf öğretmenleri ile çalışmalar yapılmıştır. Görüşmeye gönüllülük esası ve sınıf gözlemi için uygun öğretmenlerden beş öğretmen (FBÖ-7, FBÖ- 29, FBÖ-32, FBÖ-33, FBÖ-34) katılmıştır.

\section{Veri Toplama Araçları}

Çalışmada açık uçlu anket, görüşmeler ve sınıf içi gözlemler olmak üzere nitel araştırmalarda kullanılabilen üç farklı veri toplama aracından yararlanılmıştır. İlk olarak, fen bilimleri öğretmenlerinin FeTeMM eğitimi ile ilgili bilgi ve görüşlerini almak için araştırmacılar tarafından geliştirilen yedi açık-uçlu sorudan oluşan anket uygulanmıştır. Bu açık-uçlu sorular, öğretmenlerin ders içinde konuyu anlatma yöntemleri, kavramsal yeterlilikleri, alanlarındaki yeterlilikleri ve konuları değerlendirme yöntemlerine dair bilgi ve görüşlerini almak amacıyla hazırlanmıştır. Hazırlanan açık uçlu sorular alanında uzman üç araştırmacıya gönderilerek alınan dönütler doğrultusunda son haline getirilerek fen bilimleri öğretmenlerine uygulanmıştır. Ankette yer alan tüm açık uçlu sorular Ek-1 de verilmiştir.

Öğretmenlerin açık uçlu sorulara verdikleri cevaplar alındıktan sonra, derinlemesine bilgi elde etmek için katılımcılardan gönüllülük esasına uygun olarak seçilen beş öğretmen ile yarı yapılandırılmış görüşmeler yapılmıştır. Görüşmeler yaklaşık 40-50 dakika arasında, rahat ve sessiz bir ortamda ses kaydı alınarak yapılmıştır.

Son olarak görüşme yapılan öğretmenlerin açık uçlu sorulara vermiş oldukları cevaplar ile sözel olarak elde edilen bilgilerin ne ölçüde sınıf ortamında gerçekleştirilebildiğini değerlendirebilmek için yapılandırılmamış gözlemler uygulanmıştır. Elde edilen verileri desteklemek amacı ile yapılan bu gözlem türü yapılandırılmamış ortamda ve araştırmacının elinde herhangi bir somut gözlem aracı olmadan, direkt o ortamda bulunularak gerçekleştirilir (Bailey 1987, 244 akt.: Balc1, 2005). Gözlem esnasında öğretmenlerin derslerinde fen, teknoloji, mühendislik ve matematik kavramlarını birbirleri ile ilişkili bir şekilde kullanıp kullanmadıkları, eğer kullanıyorlarsa FeTeMM ile ilgili hangi yöntem/stratejileri kullandıkları ve FeTeMM disiplinlerine entegre bir şekilde kendi ölçme ve değerlendirmelerinde yer verip vermedikleri gibi kriterler göz önüne alınmıştır. 


\section{Veri Toplama Süreci}

Çalışmayı uygulayabilmek amacı ile enstitü tarafından İl Milli Eğitim Müdürlüğü’ne gönderilen yazı üç haftalık süreç sonucunda onaylanarak çalışma uygulanmaya başlanmıştır. Uygulama için Van iline bağlı merkez ilçeler (Tuşba/ İpekyolu ve Edremit) uygun görülmüştür. Gönüllülük esasına dayalı olarak öğretmenlerin katılımı ile gerçekleşen açık uçlu anket cevapları dört aylık sürede toplanmıştır. Görüşme yapılacak öğretmenler de gönüllülük esasına göre açık uçlu anketi cevaplayan öğretmenler arasından seçilmiştir. Görüşme süreci katılımcıların uygun olduğu zaman dilimleri beklenerek bir ay sürmüştür. Görüşmeye katılan öğretmenler son olarak sınıf ortamında gözlemlenmiştir. Gözlemler elde edilen bulgular birbirini tekrar edene kadar (üç hafta) sürmüştür.

\section{Verilerin Analizi}

Çalışmanın analizi içerik analizi yöntemi ile yapılmıştır. İçerik analizinin amacı verilere ulaşmak ve bu verileri açıklayabilmektir. İçerik analizinde yapılan işlem; birbirleri ile benzerlik taşıyan temalar ve kavramların anlamlı bir çerçeve altında bir araya getirilmesiyle çalışmayı inceleyenlerin anlayacağı şekilde bir bütün olarak sunulmasıdır (Yıldırım \& Şimşek, 2008). Bu çalışmada verilere ulaşabilmek ve açıklayabilmek amacı ile dokümanlardan ve görüşmelerden elde edilen veriler anlamlandırılmış temalar, kategoriler ve kodlar oluşturularak sunulmuştur. Hem açık uçlu anket sonuçları hem de görüşme sonuçları dikkatli bir şekilde incelenerek, çalışma açısından anlamlı bulunan kelimelerin, cümlelerin ve paragrafların altları çizilerek ön kodlamalar yapılmıştır. Yapılan ön kodlamadan sonra elde edilen veriler anlamlı temalar ve anlamlı kategoriler altında yapılandırılmıştır. Araştırmacılar kodlamaları tarafsız ve birbirlerinden bağımsız bir şekilde yapmışlardır. Sonrasında bir araya gelinerek kodlamalar tartışılmış ve ortak noktaya varılarak çalışmanın iç geçerliliği arttırılmıştır (Yıldırım ve Şimşek, 2013). Yapılan Kappa analizinde araştırmacılar arasında \%95 oranında yüksek tutarlılık bulunmuştur. Araştırmacılar arasındaki tutarlılığı göstermek için iki katılımcıya ait analizler verilmiştir. Kappa analizinde araştırmacıların tutarlılığı Tablo-1 ve Tablo-2'de verilmiştir. 
Tablo 1: Araştırmacılar arasındaki kategori-kod FeTeMM analizi uyumu

\author{
1.Katılımcı
}

\begin{tabular}{lll}
\hline Anket Analizi & 1. Araştırmacı & 2.Araştırmacı \\
\hline Anlam (Kavramsal) Bilgi & Kavramsal olarak & Kavramsal olarak \\
& ilişkilendirmemiş & ilişkilendirmemiş \\
Alan Bilgisi & Açıklama örneklendirilmemiş̧ & Açıklama örneklendirilmemiş \\
Farkındalık & Evet & Evet \\
İlişkisiz açıklama & İlişkisiz açıklama \\
Zorluk & Zorluk çekiyor & Zorluk çekiyor \\
& Öğretmenin zorlandı̆̆ı: Bilgi & Öğretmenin zorlandı̆̆ı: Bilgi \\
& eksikliği & eksikliği \\
& Öğrencinin zorlandı̆̆ı: & Öğrencinin zorlandı̆̆ı: \\
& teknolojiden uzak olma & teknolojiden uzak olma \\
& Araştırma inceleme & Araştırma inceleme \\
Öğretim Stratejisi & (açıklama yok) & (açıklama yok) \\
& Anlamlı öğrenme & Dersi anlamlandırma \\
Katkı & Aktif Katılım & Motivasyon artışı \\
& Gelişimlerine Katkı & Aktif Katılım \\
& & Gelişimlerine Katkı \\
Ölçme ve Değerlendirme & Kavramlar arası entegrasyonu & Kavramlar arası entegrasyonu \\
& düşünerek ölçme ve & düşnerek ölçme ve \\
& değerlendirme yapmadı & değerlendirme yapmadı \\
& Örnek yok & Örnek yok \\
& & \\
& &
\end{tabular}

Tablo 1 değerlendirildiğinde 1. katılımcı için araştırmacılar arasında bağımsız kodlamalarda yüksek tutarlılığın olduğu görülmektedir. Aynı durum Tablo 2' de görüldüğü gibi 2. katılımcı için bağımsız kodlamalar için de söylenebilir.

Tablo 2. Araştırmacılar arasındaki kategori-kod FeTeMM analizi uуumu

\title{
2.Katılımcı
}

\begin{tabular}{lll}
\hline Anket Analizi & 1. Araştırmacı & 2.Araştırmacı \\
\hline $\begin{array}{l}\text { Anlam } \\
\text { (Kavramsal) Bilgi }\end{array}$ & Kavramsal olarak ilişkilendirmiş̧ & Kavramsal olarak ilişkilendirmiş \\
Alan Bilgisi & $\begin{array}{l}\text { Açıklama var } \\
\text { Örneklendirme yok }\end{array}$ & $\begin{array}{l}\text { Açıklama var } \\
\text { Örneklendirme yok }\end{array}$ \\
Farkındalık & Evet & Evet \\
& Uygun farkındalığa sahip & Uygun farkındalığa sahip \\
Zorluk & Kismen çekiyor & Kısmen çekiyor \\
& Öğretmenin zorlandığı: & Öğretmenin zorlandığı: \\
& öğrencilerin hazırlıksız olması & öğrencilerin hazırlıksız olması \\
& Öğrencinin zorlandığı: & Öğrencinin zorlandığı: \\
& hazırlıksız gelerek derse & hazırlıksız gelerek derse \\
& katılmama & \\
& & \\
& &
\end{tabular}




\begin{tabular}{|c|c|c|}
\hline \multirow[t]{2}{*}{ Öğretim Stratejisi } & Buluş Yolu & Buluş Yolu \\
\hline & Araştırma-inceleme & Araştırma-inceleme \\
\hline Katkı & Evet & Evet \\
\hline & Bilgiyi keşfetme & Bilgiyi keşfetme \\
\hline & Düşünme becerisine sahip olma & Düşünme becerisine sahip olma \\
\hline Ölçme & Süreç odaklı & Süreç odaklı \\
\hline Değerlendirme & $\begin{array}{l}\text { Biçimlendirici: Açık uçlu soru, } \\
\text { örnek yok } \\
\text { Özetleyici: Öz değerlendirme } \\
\text { formu, örnek yok }\end{array}$ & $\begin{array}{l}\text { Biçimlendirici: Açık uçlu soru, } \\
\text { örnek yok } \\
\text { Özetleyici: Öz değerlendirme } \\
\text { formu, örnek yok }\end{array}$ \\
\hline
\end{tabular}

Katılımcılara yöneltilen soru durumlarına göre tema belirlenmiştir. Bu çalışmada katılımcıların FeTeMM ile ilgili "Farkındalık, Kavramsal Bilgi, Alan Bilgisi, Zorluk, Öğretim Stratejisi, Katkı, Ölçme ve Değerlendirme” görüşleri alınıp açık-uçlu sorular okunarak ve kategorilendirme yapılarak analiz edilmiştir. Öğretmenlerden alınan açık uçlu soru cevapları 'yeterli”, "k1smen yeterli”, “yetersiz” ve “zorlanıyor", "k1smen zorlanıyor" "zorlanmiyor” ve “evet”, "hayır” olarak kodlanmıştır. Aşağıda Tablo-3' de bu kodlamaların nasıl yapıldığı belirtilmiştir.

FeTeMM'e yönelik hazırlanan temalarda öğretmenlere sorular sorularak FeTeMM "Alan Bilgisi, Kavramsal Bilgi, Farkındalık, Zorluk, Öğretim Stratejisi, Katkı ve Ölçme Değerlendirme" olarak yedi kategori altında incelenmiştir. Öğretmenlerin FeTeMM ile ilgili yeterli bilgiye sahip olma durumları "Alan Bilgisi” kategorisi altında incelenmiştir. FeTeMM'in ne anlama geldiğini söylememeleri “Kavramsal Bilgi” kategorisi altında analiz edilmiştir. Öğretmenlerin FeTeMM ile ilgili konuları ne derece takip ediyor oldukları "Farkındalık" kategorisi altında incelenmiştir. Öğretmenlerin FeTeMM eğitimi ile ilgili çalışmalar yaparken herhangi bir zorluk yaşayıp yaşamadıkları ise "zorluk" kategorisi altında incelenmiştir. Katılımcıların FeTeMM'de bulunan dört disiplinin kavramlarının entegrasyonunu yaparken herhangi bir öğretim stratejisi kullanıp kullanmadıkları durumu ise “öğretim stratejisi” kategorisi altında analiz edilmiştir. Son olarak, öğretmenlerin FeTeMM'i sınıf ortamında değerlendirirken hangi yöntem ya da yöntemleri kullandıkları ise "Ölçme ve Değerlendirme" kategorisinde alınarak analiz edilmiştir. 
Tablo 3. Öğretmenlerin FeTeMM Görüşleri Kodlaması

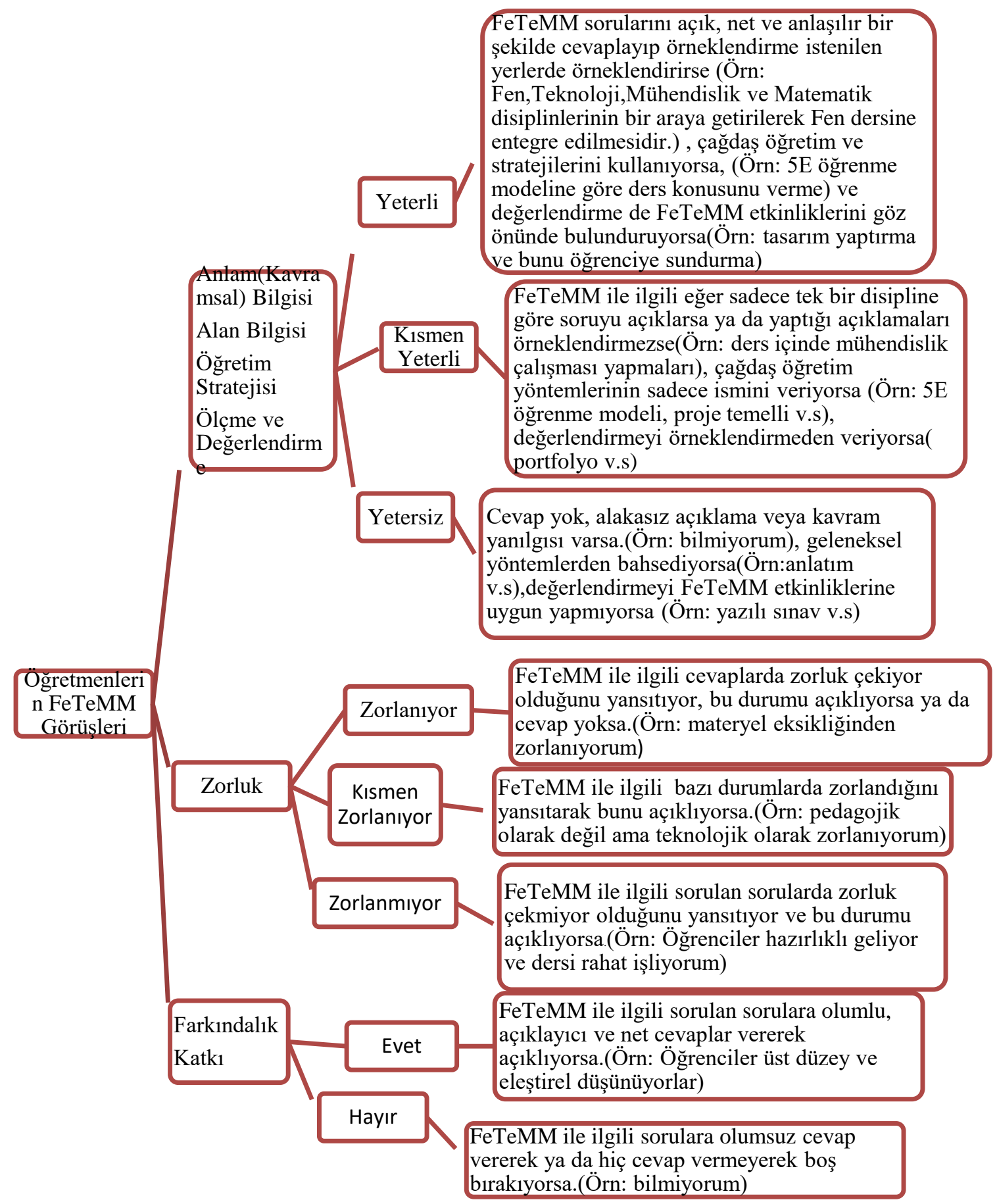

\section{Geçerlik Güvenirlik}

Yapılan bu araştırmada iç geçerliliği arttırabilecek bazı çalışmalar üzerinde durulmuştur. Yapılan çalışmalar şöyle sıralanabilir; ilk olarak katılımcıların görüşleri doğrudan alıntılar yoluyla verilmiştir. İkinci olarak üç veri toplama aracıyla (açık uçlu anket, görüşme ve gözlem) veriler toplanarak veri çeşitlemesi yapılmıştır. Yapılan çalışmanın bu şekilde üç farklı veri toplama aracı ile toplanmasına veri çeşitlemesi denir. Veri çeşitlemesi nitel çalışmalar için 
ayrı bir öneme sahiptir. Çünkü nitel çalışmaların nicel çalışmalara oranla güvenirlik bakımından daha fazla desteklenmeye ihtiyacı vardır (Marotzki, 1995). Üçüncü olarak, beş öğretmen ile yapılan görüşme verileri metne döküldükten sonra görüşme yapılan öğretmenlere teyit ettirilmiştir. Daha sonra görüşme yapılan öğretmenlerden gönüllü olan üç öğretmenin sınıf içi gözlemleri yapılmıştır. Aktarılabilirliğini (dış geçerliliği) artırmak için yapılan çalışmanın her aşamasında ayrıntıya inilerek anlatılmıştır. Ayrıca, amaçlı örneklem kullanılarak öğretmenler yapılan çalışmanın amacı doğrultusunda seçilmiş ve tanımlanmıştır. Tutarlılığı (iç geçerlilik) arttırabilmek için yapılan çalışmaya kodlar, kategoriler ve temalar oluşturulmuştur ve Kappa katsayısı \%95 olarak bulunmuştur. Teyit edilebilirlik (dış geçerliliği) sağlayabilmek için ise araştırmanın giriş kısmı, yöntem kısmı, bulgular kısmı, sonuç tartışma kısmı ve öneriler kısmı araştırmacılar tarafından ayrı ayrı kontrol edilmiştir.

\section{Bulgular}

Çalışmanın amacı fen bilimleri öğretmenlerinin değişen fen bilimleri öğretim programındaki FeTeMM eğitimi ile ilgili görüşlerini belirlemektir. Bulgular analiz kısmında bahsedilen temel tema yani FeTeMM başlığı altında sunulmuştur. Bu temel tema öğretmenler açısından sırasıyla incelenmiştir.

\section{Fen Bilimleri Öğretmenlerinin FeTeMM ile ilgili Anlam (Kavram) Bilgileri}

Fen Bilimleri öğretmenlerine yönlendirilen açı uçlu anket soruları ve yarı yapılandırılmış görüşmeler ile toplanan verilerin analiz edilmesi neticesinde katılımcıların çoğunluğunun FeTeMM'i kavramsal olarak bildikleri belirlenmiştir. Öğretmenlerin bilgi içeren açık uçlu sorulara verdikleri cevaplar analiz edilerek FeTeMM ile ilgili kavramsal bilgi kategorisi altında üç seviyeye (yeterli, kısmen yeterli ve yetersiz) göre kodlanmıştır. Bu gruplandırmaya dayalı olarak verilen cevapların frekans ve yüzdeleri Tablo-4'te gösterilmiştir.

Tablo 4. Fen bilimleri ögretmenlerinin anlam (kavram) bilgileri

\begin{tabular}{lcccccc}
\hline \multicolumn{5}{c}{ Anlam (Kavram) Bilgisi Kategorisi Kodlar } \\
\hline & Yeterli (f) & $\%$ & $\begin{array}{c}\text { Kismen } \\
\text { Yeterli (f) }\end{array}$ & $\%$ & $\begin{array}{c}\text { Yetersiz } \\
\text { (f) }\end{array}$ & $\%$ \\
\hline Açık Uçlu & 22 & $\% 52$ & 15 & $\% 32$ & 8 & $\% 16$ \\
$\begin{array}{l}\text { Sorulara } \\
\text { göre }\end{array}$ & + FBÖ-29 & & + FBÖ-7 & & & \\
öğretmen & + FBÖ-32 & & & & & \\
Say1s1 & + FBÖ-33 & & & & & \\
\hline $\begin{array}{l}\text { Görüşmeye } \\
\text { alı̈nan }\end{array}$ & 4 & & & & \\
\hline
\end{tabular}


Öğretmen FBÖ-32

Sayı1 $\quad$ FBÖ-33

FBÖ-34)

Tablo-4 incelendiğinde, açık uçlu anket sorularında FBÖ'lerin 22'si ve görüşmeye alınan FBÖ-29, FBÖ-32, FBÖ-33 ve FBÖ-34 FeTeMM'i kavramsal olarak doğru açıklayabildiği görülmüştür. Örneğin, FBÖ-10 “FeTeMM kavramsal olarak Fen, Teknoloji, Matematik ve Mühendisliği ifade ediyor. Yani; bir konuyu tam olarak hem fen boyutuyla hem teknoloji hem matematik hem de mühendislik boyutuyla ele almayı ifade ediyor. Mesela elektrik ünitesini işlerken direnç, akım, volt, gibi kavramlar Fen boyutunu, direnci hesaplamak Matematik boyutunu, konuyla ilgili ürünler gösterme ve oluşturma Mühendislik ve Teknoloji boyutunu ele alarak gerçekleşmelidir.” açıklamasını yapmıştır. Yapmış olduğu açıklamada FBÖ-10'un FeTeMM'i kavramsal olarak bildiği ve disiplinler arası bağ kurarak örneklendirebildiği görülmektedir. Yani FBÖ-10 FeTeMM ile ilgili anlamsal yeterliliğe sahiptir.

Görüşmeye alınan FBÖ-29, FBÖ-32, FBÖ-33 ve FBÖ-34 de kavramsal olarak açık uçlu sorulara ve görüşmelerde verdikleri cevaplarla yeterli olarak kodlanmışlardır. Örneğin; FBÖ34 “Kelime anlamı olarak Fen, Teknoloji, Mühendislik ve Matematik uygulamalarının derslere aktarılması olarak ifade edildiğini biliyorum. Daha çok ögrrencilerin Fen dersinde ögrrendikleri bilgilerden yola çıkarak ürün oluşturması, örnek vereyim; maket ve deneyler yapabilmesidir." Şeklinde belirterek FeTeMM kavramının anlamını örneklendirerek açıklayabilmiştir.

Bu kategoriye ait diğer bir bulgu ise, açık uçlu anket cevaplarına göre 15 FBÖ ve görüşme yapılan FBÖ-7 anlam bilgisi açısından kısmen yeterli olarak kodlanmıştır. Örneğin açık uçlu anket sorularında FBÖ-18 "Fen, Teknoloji, Matematik ve Mühendisliğin bütünleşik bir şekilde verilmesidir." Açıklamasında FeTeMM'in baş harflerinden yola çıkarak sadece adlarını söylemek şeklinde olmuştur. Bu bakımdan FBÖ-18 yapmış olduğu açıklama disiplinler arası bütünlükten bahsetmediği ve örneklendirme yapamadığı için kısmen yeterli kabul edilmiştir.

Görüşmeye alınan FBÖ-7 “FeTeMM kavramsal olarak teknoloji ve mühendisliğin fen bilimlerine uyarlanmasıdır'" açıklamasını hem açık uçlu ankette hem de görüşmede tekrar etmiştir. Görüşmede verdiği cevabı örneklendirmesi istendiğinde açık uçlu anket sorusuna verdiği cevabı tekrarlamış ve herhangi bir örneklendirme yapmamıştır. Böylece katılımcının disiplinler arası bağ kurarken eksiklikleri olduğu için kısmen yeterli olarak kodlanmıştır. 
Son olarak bu kategori altındaki Tablo-4'e bakıldığında, açık uçlu ankete cevap veren sekiz FBÖ’nün anlam bilgisi yönünden yetersiz olduğu belirlenmiştir. FBÖ-30 “Teknolojinin ve yeniliğin derslere uygulanması. Örnek çarkları anlatırken bunlara nasıl yön veririz bunu da anlatmalıyız." Şeklinde bir açıklamada bulunmuştur. FBÖ-30’un yapmış olduğu açıklama FeTeMM kavramlarından uzak bir açıklama olduğu için yetersiz olarak değerlendirilmiştir.

\section{Fen Bilimleri Öğretmenlerinin FeTeMM ile ilgili Alan Bilgileri}

Fen Bilimleri öğretmenlerine yönlendirilen açık uçlu anket soruları, yarı yapılandırılmış görüşmeler ve gözlem ile toplanan verilerin analiz edilmesi neticesinde; katılımcıların çoğunluğunun FeTeMM ile ilgili yeterli alan bilgisine sahip olmadıkları tespit edilmiştir. Yeterli olduklarını dile getirerek açıklamada bulunan öğretmenlerin yapmış oldukları açıklamaların ise yeterlilikleri ile fazla uyuşmadığı görülmektedir. Öğretmenlerin bilgi içeren açık uçlu sorulara verdikleri cevaplar analiz edilerek FeTeMM ile ilgili alan bilgisi kategorisi altında üç seviyeye (yeterli, kısmen yeterli ve yetersiz) göre kodlanmıştır. Bu gruplandırmaya yönelik frekans ve yüzdeler Tablo-5'te gösterilmiştir. Tablo-5 incelendiğinde, açık uçlu anket sorularında FBÖ’lerin hiçbirinin ve görüşmeye alınan öğretmenlerin hiçbirinin FeTeMM hakkında yeterli alan bilgisine sahip olmadığı görülmüştür.

Tablo 5. Fen bilimleri ögretmenlerinin alan bilgisi

\begin{tabular}{|c|c|c|c|c|c|c|}
\hline \multicolumn{7}{|c|}{ Alan Bilgisi Kategorisi Kodlar } \\
\hline & $\begin{array}{l}\text { Yeterli } \\
\text { (f) }\end{array}$ & $\%$ & $\begin{array}{c}\text { Kismen } \\
\text { Yeterli (f) }\end{array}$ & $\%$ & $\begin{array}{l}\text { Yetersiz } \\
\text { (f) }\end{array}$ & $\%$ \\
\hline $\begin{array}{l}\text { Açık Uçlu } \\
\text { Sorulara } \\
\text { göre } \\
\text { ögrretmen } \\
\text { Sayısı }\end{array}$ & 0 & $\% 0$ & $\begin{array}{c}23 \\
+ \text { FBÖ-32 } \\
+ \text { FBÖ-33 } \\
+ \text { FBÖ-34 }\end{array}$ & $\% 52$ & $\begin{array}{c}22 \\
+ \text { FBÖ-29 } \\
+ \text { FBÖ-7 }\end{array}$ & $\% 48$ \\
\hline $\begin{array}{l}\text { Görüşmeye } \\
\text { alınan } \\
\text { Öğretmen } \\
\text { Sayıs1 }\end{array}$ & - & & $\begin{array}{c}2 \\
\text { (FBÖ-32, } \\
\text { FBÖ-33) }\end{array}$ & & $\begin{array}{c}3 \\
\text { (FBÖ-29 } \\
\text { FBÖ-7 } \\
\text { FBÖ-34) }\end{array}$ & \\
\hline
\end{tabular}

Açık uçlu ankete cevap veren yirmi iki ve görüşme yapılan iki FBÖ’nün alan bilgisi yönünden yetersiz olduğu belirlenmiştir. Örneğin; FBÖ-9 “Yeterli olduğumu düşünmüyorum. Ancak sınıflar daha az kişilik ve materyal desteği olursa araştırmalarımı arttırıp daha verimli olabilirim." açıklamasında bulunmuştur. Yapmış olduğu bu açıklama ile FeTeMM alan 
bilgisinde eksik olduğunu ve şartlar öğretim ortamlarına göre düzenlenirse bu konuda kendisini geliştirebileceğini vurgulamıştır.

Görüşmeye alınan öğretmenlerin açık uçlu sorulara ve görüşmelerde sorulan sorulara uygun cevap veremediklerinden dolayı FeTeMM' e yönelik alan bilgisi yetersiz olarak kodlanmıştır. Görüşme yapılan FBÖ-34 ve FBÖ-7 ve FBÖ-29 yetersiz olarak kodlanmıştır. FBÖ-7 “Öğretim ortamlarının FeTeMM temelinde yapılandırılmasında yeterli alan bilgisine sahip olduğumu düşünmüyorum. Bu yüzden FeTeMM hakkında biz ögretmenlere ĕgitim verilmesinin yararlı olacağını düşünüyorum." ş̧eklinde ifade ederek bu konuda yetersiz olduğunu dile getirmiştir. FBÖ-7 hem uygulanan ankette hem de görüşme esnasında aynı ifadeleri kullanmıştır.

Bu kategoriye ait diğer bir bulgu ise, açık uçlu anket cevaplarına göre yirmi üç FBÖ ve görüşme yapılan FBÖ-32, FBÖ-33 ve FBÖ-34 kısmen yeterli olarak kodlanmıştır. Örneğin açık uçlu anket sorusuna FBÖ-50 "Yeterli alan bilgisine sahibim çünkü teknolojiyi kullanarak projeler üretmek güncel bir durum olduğundan takip edebiliyorum” açıklamasını yaparak alan bilgisinde kısmen yeterli kategorisine dahil edilmiştir. Yapmış olduğu açıklamada FBÖ-50 FeTeMM çalışmalarında teknolojiden yararlanarak proje ürettiğini ve güncel işleyişi takip ettiğini dile getirmiştir fakat açıklamasını örneklendirmemiş olduğu için kısmen yeterli kabul edilmiştir.

Görüşmeye alınan FBÖ-33 'FeTeMM’i kapsayan dört branş kendi içinde yeterince geniş ve ben fen bilimleri ögretmeniyim, kendi alanımda bir yere kadar yeterli olabilirim. Teknoloji, Matematik, Mühendislik bunlarda çocuklara tamamen olmasa bile klsmen yeterli olabileceğimi düşünüyorum. Çünkü içinde fen de dahil olmak üzere çok geniş alanlar, ben ögretmenlerin bu konuda dört dörtlük bir tecrübeye sahip olabileceğini veya dört dörtlük bir alan bilgisine sahip olabileceğini düşünmüyorum. Fen bilimlerinde evet yeterliyim ama diğer alanlar için aynı şeyi söyleyemem"' şeklinde cevap vermiştir. FBÖ-33 FeTeMM kapsamında bulunan alanlardan sadece fen bilimlerine tam anlamı ile hâkim olduğunu, diğer üç alana tam hâkim olmadığını dile getirdiği için kısmen yeterli olarak görüşmüştür.

Yapılan görüşmeler sonrasında sınıf içinde gözlemlenen öğretmenlerin sınıf ortamında konu ile ilgili kavramlar disiplinler arası entegrasyon yapılmadan tek disiplinli olarak açıklanmıştır. Örneğin; sınıf ortamında gözlemlenen FBÖ-7 kodlu öğretmen 6.sınıfa "Kuvvet ve Hareket' 'ünitesini işlerken kuvvet ve hareketi sadece fizik boyutunda anlatarak disiplinler arası bütünleştirme yapmadan tek disiplinli anlatım gerçekleştirdiği görülmüştür. 


\section{Fen Bilimleri Öğretmenlerinin FeTeMM ile İlgili Farkındalıkları}

Fen Bilimleri öğretmenlerine yönlendirilen açık uçlu anket soruları ve yarı yapılandırılmış görüşmeler ile toplanan verilerin analiz edilmesi neticesinde; öğretmenlerin FeTeMM ile ilgili farkındalıklarının olduğu ama bu farkındalıkları dile getirirken ilişki kuramadıkları tespit edilmiştir. Öğretmenlerin bilgi içeren açık-uçlu sorulara verdikleri cevaplar analiz edilerek FeTeMM ile ilgili farkındalıkları iki şekilde (evet, hayır) kodlanmıştır. Verilen cevaplar arasındaki ilişskilendirmeler de araştırılarak cevaplara yansıtılmıştır. $\mathrm{Bu}$ gruplandırmaya dayalı olarak verilen cevapların yüzde ve frekansları da Tablo-6'da gösterilmiştir.

Tablo 6. Fen bilimleri ögretmenlerinde farkındalık

\begin{tabular}{lcccc}
\hline \multicolumn{4}{c}{ Farkındalık Kategorisi Kodlar } & \\
\hline & Evet (f) & $\%$ & Hayır (f) & $\%$ \\
\hline Açık Uçlu Sorulara & 42 & $\% 94$ & 3 & $\% 6$ \\
göre öğretmen & + FBÖ-7 & & & \\
Sayısı & + FBÖ-29 & & \\
& + FBÖ-32 & & \\
& + FBÖ-33 & & \\
& + FBÖ-34 & & \\
\hline Görüşmeye alınan & 5 & & \\
Öğretmen Sayıs1 & (FBÖ-7, & & \\
& FBÖ-29 & & \\
& FBÖ-32 & & \\
& FBÖ-33 & & \\
& FBÖ-34) & & \\
\hline
\end{tabular}

Tablo-6 incelendiğinde, açık uçlu anket sorularında FBÖ’lerin 42'si ve görüşmeye alınan FBÖ-7, FBÖ-29, FBÖ-32, FBÖ-33 ve FBÖ-34'un FeTeMM'e dair farkındalıklarının olduğu görülmüştür. FBÖ-2 "Evet”' cevabını vererek, “Öğrencilerin bilgi düzeyinin değerlendirilmesinden ziyade ögrencinin bilgiyi keşfetmesi ve keşfedilen bilgiye dair taslaklar oluşturarak günlük hayatta kullanma olanağı sunması şeklinde entegre edilebilir', açıklaması ile FeTeMM'in fen bilimleri dersine nasıl entegre edilebileceğine dair görüş bildirmiştir. Yaptığı açıklama ile farkındalığını dile getirmiş ve açıklamış olduğu için “evet” kategorisine dahil edilmiştir.

Açık uçlu ankete cevap veren 3 öğretmen “Hayır”' cevabını vererek açıklamada bulunmamışlardır. Örneğin, “FBÖ-48 cevabında “inceledim”, söyleminde bulunmuştur. FBÖ48 “inceledim” 'söyleminden sonra “örnek olarak ormansızlaştırma üzerine bir tema seçsinler. Google earth'dan belli bir bölgenin beş yll önceki fotoğrafıyla bugün ki fotoğrafina 
bakılabilir." şeklinde vermiş olduğu cevap ile desteklemek istemiştir. Katılımcının yapmış olduğu bu açıklama ile FeTeMM farkındalığı arasında ilişki kurulamadığı görüldügü için ‘'hayır'” olarak görülmüştür. FBÖ- 43 ' 'Hayır'” cevabını vermiştir. Katılımcı farkındalığının olmadığını açık şekilde belirtmiştir.

Görüşmeye alınan FBÖ-7, FBÖ-29, FBÖ-32, FBÖ-33 ve FBÖ-34 “Evet” cevabını vermiştir. FBÖ-7, FBÖ-29, FBÖ-32 ve FBÖ-33'ün verdikleri "Evet” cevabı açıklamaları ile ilişkilendirilebilirken, FBÖ-34'ün verdiği ' Evet”' cevabı açıklaması ile ilişkilendirilememiştir. Örneğin; FBÖ-33 “Evet inceledim. ' cevabını vererek devamında', Ders kitaplarının sonunda yer almasından ziyade ünite içerisine entegre edilirse daha uygun olacă̆ını düşünüyorum. Hem çocuk bilgilerini de kullanarak konuyu pekiştirmiş olacaktır." cevabını vererek ilişkilendirmiştir. Görüşme yapılan öğretmenlerin farkındalık sorularına verdikleri anket cevapları ile görüşme esnasında verdikleri cevaplarının da birbiri ile uyuştuğu görülmektedir.

Son olarak bu kategori altındaki Tablo-6'ya bakıldığında, açık uçlu ankete cevap veren üç öğretmen "Hayır" cevabını vererek açıklamada bulunmamışlardır. Örneğin, FBÖ-48 cevabında "inceledim" söyleminde bulunmuştur. FBÖ-48 "inceledim” söyleminden sonra “örnek olarak ormansızlaştırma üzerine bir tema seçsinler. Google earth'dan belli bir bölgenin beş yıl önceki fotoğrafiyla bugün ki fotoğrafina bakılabilir." Şeklinde vermiş olduğu cevap ile desteklemek istemiştir. Katılımcının yapmış olduğu bu açıklama ile FeTeMM farkındalığı arasında ilişki kurulamadığı görüldüğü için “Hayır” olarak görülmüştür.

\section{Fen Bilimleri Öğretmenlerinin FeTeMM’e Dair Zorluk Durumları}

Fen Bilimleri öğretmenlerine yönlendirilen açı uçlu anket soruları ve yarı yapılandırılmış görüşmeler ile toplanan verilerin analiz edilmesi neticesinde; katılımcıların FeTeMM ile ilgili fazlasıyla zorlandıkları belirlenmiştir. Öğretmenlerin zorlandıkları durumların öğretmenden kaynaklı kısımları ve öğrenciden kaynaklı kısımları analizlerle açıklanmıştır. Öğretmenlerin bilgi içeren açık-uçlu sorulara verdikleri cevaplar analiz edilerek FeTeMM ile ilgili zorlanma durumu kategorisi üç seviyeye (çekiyor, çekmiyor, kısmen çekiyor) göre kodlanmıştır. Verilen cevaplar arasındaki ilişkilendirmeler de araştırılarak cevaplara yansıtılmıştır. Bu gruplandırmaya dayalı olarak verilen cevapların yüzde ve frekansları Tablo-7'de gösterilmiştir. 
Tablo7. Fen bilimleri ögretmenlerinin zorluk durumlarl

\begin{tabular}{|c|c|c|c|c|c|c|}
\hline \multicolumn{7}{|c|}{ Zorluk Kategorisi Kodlar } \\
\hline & $\begin{array}{l}\text { Zorlaniyor } \\
\text { (f) }\end{array}$ & $\%$ & $\begin{array}{l}\text { Kismen } \\
\text { Zorlaniyor } \\
\text { (f) }\end{array}$ & $\%$ & $\begin{array}{l}\text { Zorlanmiyor } \\
\text { (f) }\end{array}$ & $\%$ \\
\hline $\begin{array}{l}\text { Açık Uçlu } \\
\text { Sorulara } \\
\text { göre } \\
\text { ögrretmen } \\
\text { Sayısı }\end{array}$ & $\begin{array}{c}\text { 30 } \\
+ \text { + FBÖ-7 } \\
+ \text { FBÖ-32 } \\
+ \text { FBÖ-34 }\end{array}$ & $\% 66$ & 13 & $\% 26$ & $\begin{array}{c}2 \\
+ \text { FBÖ-29 } \\
+ \text { FBÖ-33 }\end{array}$ & $\% 8$ \\
\hline $\begin{array}{l}\text { Görüşmeye } \\
\text { alınan } \\
\text { Öğretmen } \\
\text { Sayıs1 }\end{array}$ & $\begin{array}{c}3 \\
\text { (FBÖ-7, } \\
\text { FBÖ-32, } \\
\text { FBÖ-34) }\end{array}$ & & $\begin{array}{c}2 \\
\text { (FBÖ-29, } \\
\text { FBÖ-33) }\end{array}$ & & & \\
\hline
\end{tabular}

Tablo-7 incelendiğinde, açık uçlu anket sorularında FBÖ’lerin 30'u ve görüşmeye alınan FBÖ-7, FBÖ-32 ve FBÖ-34'ü pedagojik ve teknolojik olarak zorlanırken, bu zorlanma durumlarında; öğretmenden kaynaklı zorlanmaları ve öğrenciden kaynaklı zorlanmaları açıklamışlardır. FBÖ-26 “Evet zorlanıyorum. FeTeMM'de bence öncelikle okulun teknolojik ve pedagojik ortamı düzenlenmeli. Bulunduğumuz okul ortamı dezavantajlı ortam olduğu için zorlanıyorum" söylemi ile kendisinin zorlanma sebebini çevresel şartlara bağlamıştır.

Görüşmeye alınan FBÖ-7, FBÖ-32 ve FBÖ-34 de FeTeMM ile ilgili zorlandıklarını belirtmişlerdir. FBÖ-7 “Evet zorluk çekiyorum. Zorluk çekmemin sebebi FeTeMM hakkında bilgilendirilmemiş olmam ve bu konuda eğitim almamış olmam." açıklaması ile FeTeMM'e dair bilgi eksikliğinden dolayı zorlandığını hem ankette hem de görüşmede belirtmiştir. FBÖ7 “Öğrencilerin zorlandı̆̆ d durumlar ise; fen bilimlerinin FeTeMM'e nasıl uygulanması gerektiğini bilmemeleri” açıklaması ile öğrencilerin zorlandığı durumu aktarmaktadır.

Bu kategoriye ait bir diğer bulgu ise, açık uçlu anket sorularına göre 13 FBÖ kısmen zorlandığını belirtmiştir. Örneğin açık uçlu anket sorularında FBÖ-20 "Bazen zorlanıyorum. Okul sistemi FeTeMM'e uygun olmadiğg için uygulamalı ders anlatmak zor oluyor." şeklinde yapmış olduğu açıklaması ile aslında pedagojik olarak değil ama uygulama alanı olmadığından teknolojik olarak zorlandığını dile getiriyor. Bu yüzden FBÖ-20 kısmen zorluk çekiyor kategorisine dahil edilmiştir. Öğrencilerin zorlandığı durumu ise FBÖ-20 “Anlatılan konuları uygulayamadıkları için kalıcı öğrenme gerçekleşmiyor." şeklinde dile getirerek öğrencilerin zorlanma durumlarının da yine teknolojik ortam eksikliğinden kaynaklı olduğunu yani uygulama alanı olmadı̆̆ından zorlandıklarını dile getirmiştir. 
Son olarak bu kategori altındaki Tablo-7'ye bakıldığında, açık uçlu ankete cevap veren FBÖ-37 ve FBÖ-24'ün görüşmeye alınan öğretmenlerden ise FBÖ-29 ve FBÖ-33 zorlanmadıklarını belirtmişlerdir. Örneğin; FBÖ-37 "FeTeMM temelinde teknolojik ve pedagojik zorluk çekmiyorum. Çünkü bununla ilgili gerekli uygulamalı eğitim aldım. " cevabını veren FBÖ-37 daha sonrasında kendisinin zorlanmadığı ama öğrencilerin zorlandığı durumları “Öğrenciler fen, matematik, teknolojik ve mühendislik disiplinlerini bir arada kullanmakta zorlanıyorlar." şeklinde açıklamıştır. Zorluk çekmediklerini söyleyen öğretmenlerimizin büyük çoğunluğu her ne kadar kendileri zorlanmasalar da eğitim ortamının ve çocukların henüz FeTeMM' e uygun olmadığını dile getirmişlerdir.

Görüşmeye alınan FBÖ-29 ve FBÖ-33 açık uçlu cevaplarda zorlanmadıklarını belirtseler de görüşme sonucunda her iki katılımcıda kısmen zorlanıyor kategorisine alınmıştır. Örneğin FBÖ-33 "Sinıf ortamlarımız FeTeMM temelli etkinlikler için yani teknolojik boyutlu yeterli değil. Pedagojik olarak bilgiye ne kadar sahip olursanı olun öğrenci bireysel farklılıkları işin içine girince bilgiler de bir yere kadar yeterli oluyor. Bu konuda sıkıntı yaşayabiliyorum. Çünkü bireysel farklllıklar sinıfta ciddi problemlere neden oluyor. Benim zorlandı̆̆ım en büyük problem ders esnasında öğrencilerin birbirlerinden aynı performansı beklemesi. Bunun dışında ciddi bir problemle karşılaşmıyorum. ” Açıklamasını yaparak aslında pedagojik olarak yeterli olduğunu ama uygulanabilir sınıf ortamı olmadığından öğrenci farklılıklarına yetişemediğini ve bu durumda yani teknolojik eksiklik noktasında zorlandığını dile getiriyor. FBÖ-33 pedagojik olarak yeterli fakat teknolojik ve uygulanabilirlik yönünden sıkıntı yaşadığından kısmen yeterli kategorisinde ele alınmaktadır. FBÖ-33 öğretmen öğrencilerin zorlandığı durumu ise "sınıfımız teknolojik olarak uygun olmadığ malzemeleri kendileri getiriyorlar. Ister istemez malzeme temininde sıkıntı yaşıyorlar. Bulamadıklarını söylüyorlar. Motivasyon eksikliği yaşıyorlar. Ístedikleri gibi bir proje geliştiremeyeceklerine ve yapamayacaklarına inanıyorlar. Bununla ilgili sıkıntı yaşlyorlar." şeklinde açıklayarak yine okul ortamlarının teknolojik olarak FeTeMM temelinde çalışma yapmaya henüz uygun olmadığını ve çocukların bu sürece ayak uydurmakta zorlandıklarını dile getirerek zorlanma durumlarını göstermektedir.

Sınıf içi gözlem yapılan öğretmenlerden FBÖ-7'nin anket ve görüşmelerde de belirttiği gibi ders anlatımı yaparken zorlandığı gözlemlenmiştir. Örneğin; FBÖ-7 okuldaki akıllı tahta eksikliğinden kaynaklı öğrencilere online programlarla ders anlatımı yapamadığı gözlemlenmiştir. Teknolojik olarak eksikliği olan ve bu konuda zorlanan FBÖ-7 kodlu 
öğretmen 7.sınıf öğrencilerine atom ve molekülleri tahtaya çizerek aktarmıştır. Öğrencilere dersi sadece kimya boyutunda aktaran öğretmenin, disiplinler arası entegrasyon kurmakta zorlandığı gözlemlenmektedir. Sınıf içi gözlem yapılan öğretmenlerden FBÖ-29 ve FBÖ-33'ün anket ve görüşmelerde de belirttikleri gibi ders anlatımı yaparken kısmen zorlandıkları gözlemlenmiştir. Örneğin; FBÖ-29 daha önce de belirtmiş olduğu gibi, disiplinler arası alan bilgisi eksikliğinden dolayı öğrencilere atom ve molekülleri anlatırken FeTeMM'e uyarlama yapamamıştır. FeTeMM ile ilgili yeterli alan bilgisine sahip olmaması konuyu örneklendirmede ve öğrencinin anlayacağı düzeyde aktarmada zorlandığg görülmüştür.

\section{Fen Bilimleri Öğretmenlerinin FeTeMM ile ilgili Öğretim Stratejileri}

Fen Bilimleri öğretmenlerine yönlendirilen açık uçlu anket soruları, yarı yapılandırılmış görüşmeler ve yapılandırılmamış gözlemler ile toplanan verilerin analiz edilmesi neticesinde; FBÖ’lerin çoğunluğunun FeTeMM ile ilgili yeterli strateji kullanamadıkları belirlenmiştir. Yeterli olduklarını dile getirerek açıklamada bulunan öğretmenlerin kullanmış oldukları strateji açıklamalarının ise yeterlilikleri ile fazla uyuşmadığı görülmektedir. Öğretmenlerin bilgi içeren açık-uçlu sorulara verdikleri cevaplar analiz edilerek FeTeMM ile ilgili kullandıkları stratejileri kategorisi altında üç seviyeye (yeterli, kısmen yeterli ve yetersiz) göre kodlanmıştır. Bu gruplandırmaya dayalı olarak verilen cevapların yüzde ve frekansları da Tablo-8'de gösterilmiştir.

Tablo 8. Fen bilimleri ögretmenlerinin ögretim stratejisi

\begin{tabular}{|c|c|c|c|c|c|c|}
\hline \multicolumn{7}{|c|}{ Öğretim stratejisi Kategorisi Kodlar } \\
\hline & Yeterli (f) & $\%$ & $\begin{array}{l}\text { Kismen } \\
\text { Yeterli } \\
\text { (f) }\end{array}$ & $\%$ & $\begin{array}{l}\text { Yetersiz } \\
\text { (f) }\end{array}$ & $\%$ \\
\hline $\begin{array}{l}\text { Açık Uçlu } \\
\text { Sorulara } \\
\text { göre } \\
\text { öğretmen } \\
\text { Sayıs1 }\end{array}$ & $\begin{array}{c}8 \\
+ \text { FBÖ-29 }\end{array}$ & $\% 18$ & $\begin{array}{c}14 \\
+ \text { FBÖ-33 }\end{array}$ & $\% 30$ & $\begin{array}{c}23 \\
+ \text { FBÖ-7 } \\
+ \text { FBÖ-32 } \\
+ \text { FBÖ-34 }\end{array}$ & $\% 32$ \\
\hline $\begin{array}{l}\text { Görüşmeye } \\
\text { alınan } \\
\text { Öğretmen } \\
\text { Sayısı }\end{array}$ & 1(FBÖ-29) & & 1(FBÖ-33) & & $\begin{array}{c}3 \\
\text { (FBÖ-7, } \\
\text { FBÖ-32, } \\
\text { FBÖ-34) }\end{array}$ & \\
\hline
\end{tabular}

Tablo-8 incelendiğinde, açık uçlu anket sorularında FBÖ’lerin sekizi ve görüşmeye alınan FBÖ-29'un FeTeMM öğretim stratejilerinde yeterli olduğu görülmüştür. Örneğin; FBÖ5 “Fen, Teknoloji, Matematik, Mühendislik disiplinlerinin hangi amaca hizmet ettikleriyle ilgili 
ögrencilere bilgi veriyorum. FeTeMM temelinde ders işlerken daha çok buluş yöntemini kullanıyorum. Araştırma, geliştirme yaparak öğrenci deney üzerinde bizzat çalışıp öznel bilgisini ortaya çıkarıyor. Daha çok gurup etkileşimine dayanan iş birlikli yaklaşımları seviyorum. ”şeklinde açıklama yapmıştır. Yapmış olduğu açıklamada hem öğretim stratejilerini doğru bir şekilde verip hem de FeTeMM'e uygun olarak sınıf ortamında nasıl kullandığını açıklamıştır. FBÖ-5 öğretim stratejilerini doğru seçerek uygulamasını açıklamış olduğu için yeterli kategorisinde kabul edilmiştir.

Görüşme yapılan FBÖ-29'da öğretim stratejilerini nasıl kullandığı ile ilgili yapılan anket ve görüşmenin cevaplarına göre yeterli olarak kodlanmıştır. FBÖ-29 "Hepsini kullanıyorum. Örneğin; araştırma-incelemeyi; tasarım geliştirirken, teknolojik ürün oluştururken, sunuşu; fen ve matematik bilgisini edinmeleri gerektiğinde, buluş yöntemini de derslerin başında problem durumunda kullanıyoruz"” açıklamaları ile FBÖ-29 kodlu öğretmen hem öğretim stratejilerini doğru bir şekilde adlandırmış hem de FeTeMM etkinliklerinde nasıl kullandığını açıklamıştır. FeTeMM'e dair en önemli süreçlerden biri olan tasarıyı da sınıf ortamında kullanarak anket çalışmasında ve görüşmede eş değer açıklamalar yaptığı için yeterli kategorisinde ele alınmıştır.

Bu kategoriye ait diğer bir bulgu ise, açık uçlu anket cevaplarına göre 14 FBÖ ve görüşme yapılan bir öğretmen öğretim stratejileri yönünden kısmen yeterli olarak kodlanmıştır. Örneğin açık uçlu anket sorularında FBÖ-9 "Yaparakyaşayarak ögrenme stratejisi, uygulamalı eğitim. " cevabını vermiştir. Öğretmenin kullandığı yöntemlerde öğrencinin sürece dâhil olması ve aktif olarak çalışması FeTeMM'in uygulanabilirliği açısından gereklidir. Fakat öğretmen kullanmış olduğu öğretim stratejilerini sadece başlık halinde verdiği ve açıklamalı bir şekilde aktarmadığı için kısmen yeterli kategorisinde dâhil edilmiştir.

Görüşmeye alınan FBÖ-33 “Araştırma- Inceleme veya Buluş yolu ile ögrenme gibi stratejileri kullaniyorum." açıklaması ile FeTeMM'e dair doğru öğretim stratejileri kullandığını fakat nasıl kullandığını açıklamadığından dolayı kısmen yeterli kategorisine kodlanmıştır. Sınıf içi gözlem yapılan öğretmenlerin geleneksel yöntemlerinden sunuş yolu ile öğretimi tercih ettikleri ve öğrencilerin de bu sisteme alışmış olarak ders içi sorgulamalar yapmadıkları gözlemlenmiştir.

Son olarak bu kategori altındaki Tablo 8'e bakıldığında, açık uçlu ankete cevap veren 23 ve görüşmeye alınan üç öğretmen öğretim stratejisi yönünden yetersiz olarak kodlanmıştır. Örneğin; FBÖ-26 “Argümantasyon tabanlı bilim öğrenme” olarak adlandırdığı yöntem strateji 
açıklayıcı olmamaktadır. Öğretmen FeTeMM'i kullanırken uyguladığı öğretim stratejisini nasıl kullandığını açıklamadığı ve sadece bir başlık olarak vermiş olduğu için yetersiz olarak kodlanmıştır.

Görüşmeye alınan FBÖ-34 “Laboratuvar ortamının olmamasından dolayı ben daha çok gösterip yaptırma yöntemini kullanıyorum. Çünkü çocuklara daha fazla temas edebilecekleri, kendilerini ait hissedebilecekleri bir ortam olmadiğı için en fazla bunu yapabiliyorum." açıklamasını hem ankette hem de görüşmede dile getirmiş ve FeTeMM'de kullanılabilecek öğretim stratejilerinin uzağında kalarak konu dışında bir açıklamada bulunmuştur. Gösteripyaptırma tekniği ile öğrenciler yeni bir ürün tasarlayamayacakları için yetersiz olarak kodlanmıştır.

Sınıf ortamında gözlemlenen öğretmenlerden FBÖ-33 “'Kuvvet ve Hareket” ünitesini anlatırken, kuvvetin ve hareketin ne olduğunu sözel ifadelerle anlattıktan sonra tahtaya kuvvet soruları yazarak konuyu matematiksel veriler kullanarak çözmelerini istemiştir. Öğrencilere konuyu aktarmakta teknolojik koşullardan ve kuvvet ve hareketle ilgili tasarımlar oluşturmalarını istemediğinden ve sınıf ortamında sunuş yolunu aktif olarak kullandığı için yetersiz görülmüştür. FBÖ-33'ün 5.sınıf öğrencilerine "kuvvetin ölçülmesi' ile ilgili beyin firtınası yaptırması ve sonrasında problem senaryoları yazdırması FeTeMM'e dair tam anlamıyla yeterli olmayan stratejiler kullandığını göstermiştir. Her ne kadar problem senaryoları fen bilimleri dersi ile matematik ve teknolojiyi bağdaştırsa da tasarı olmadığı için mühendislik bunun dışında kalmaktadır.

\section{Fen Bilimleri Öğretmenlerinin FeTeMM'in Katkısı ile ilgili Görüşleri}

Fen Bilimleri öğretmenlerine yönlendirilen açık uçlu anket soruları ve yarı yapılandırılmış görüşmeler ile toplanan verilerin analiz edilmesi neticesinde; FBÖ’lerin hepsi FeTeMM temelli öğretim ortamlarının öğrenci çıktılarına olumlu katkı sağlayacağı görüşünde oldukları tespit edilmiştir. Belli sayıda öğretmen bu konuyla ilgili hiç görüş bildirmemiştir. Öğretmenlerin bilgi içeren açık-uçlu sorulara verdikleri cevaplar analiz edilerek FeTeMM'in öğrenci çıktılarına katkısı kategorisi altında iki seviyeye (evet, hayır) göre kodlanmıştır. Bu gruplandırmaya dayalı olarak verilen cevapların yüzde ve frekansları da Tablo 9'de gösterilmiştir. 
Tablo 9. Fen bilimleri öğretmenlerinin katkı görüşleri

\begin{tabular}{lcccc}
\hline & \multicolumn{3}{c}{ Katk1 Kategorisi Kodlar } & \\
\hline & $\begin{array}{c}\text { Evet } \\
(\mathrm{f})\end{array}$ & $\%$ & $\begin{array}{c}\text { Hayır } \\
(\mathrm{f})\end{array}$ & $\%$ \\
\hline Aç1k Uçlu & 37 & $\% 84$ & 8 & \\
Sorulara göre & + FBÖ-7 & & & \\
öğretmen Say1s1 & + FBÖ-29 & & & \\
& + FBÖ-32 & & \\
& + FBÖ-33 & & \\
& + FBÖ-34 & & \\
Görüşmeye & 5 & & \\
alı̈nan & FBÖ-7, & & \\
Öğretmen & FBÖ-29, & & \\
Sayıs1 & FBÖ-32, & & \\
& FBÖ-33, & & \\
& FBÖ-34) & & & \\
\hline
\end{tabular}

Tablo-9 incelendiğinde, açık uçlu anket sorularında FBÖ’lerin 37'si ve görüşmeye alınan FBÖ7, FBÖ-29, FBÖ-32, FBÖ-33 ve FBÖ-34 FeTeMM'in öğrenci çıktılarına katkısının olumlu yönde olduğunu belirtmiştir. Yani FeTeMM'in öğrenci çıktılarına olumlu yönde etki edeceğini düşünerek “Evet”' şeklinde görüşlerini bildirmişlerdir. Örneğin; FBÖ-5 "FeTeMM temelli yapılandırılmış bir ortamda öğrenci üst düzey düşünme becerilerine sahip bireyler olarak yetişeceklerdir. Yapılan uygulamalar sayesinde teorik bilgi pratik bilgiye dönüşecek, dersler keyifli hale gelecek ve böylece kendini gerçekleştirmiş, topluma faydası olan genç beyinler yetişecektir." açıklamasında bulunmuştur. Yapmış olduğu açıklama ile FeTeMM'in öğrenci çıktılarına katkı sağlayacağını ve bu katkının olumlu yönde olacağını belirtmiştir. FeTeMM sayesinde üst düzey düşünebilen, kendini gerçekleştirebilen bireyler yetişeceğini söyleyerek FeTeMM'in öğrenci çıktılarına olumlu yönde katkı sağlayacağını belirtmiştir.

Görüşmeye alınan FBÖ-7, FBÖ-29, FBÖ-32, FBÖ-33 ve FBÖ-34'ün açık uçlu sorulara ve görüşmelere verdikleri cevaplar evet olarak kodlanmıştır. Örneğin; FBÖ-29 olarak kodlanan öğretmen “21.yy’da öğrenci yetiştirdiğim şu dönemde FeTeMM’e inanmamı gerektiğini düşünüyorum. Çünkü gelişen bir dünya var her şey çok hızlı değişiyor. Artık bilgiyi gerçekten kullanan olmanız gerekiyor. Hani üretenden ziyade artı tüketen olması gerekiyor. Bilgiyi kullanarak ürüne çevirebilen insanlar yetiştirmemiz gerekiyor. Bunu da yapabileceğimiz bir ögretim yöntemi FeTeMM'dir. Ĕger gerçekten doğru bir şekilde uygulanırsa yani sonuçlarının, çıktılarının olumlu olacă̆ını düşünüyorum. Problem çözme becerisi, iletişim becerisi, eleştirel düşünme becerisi gelişmiş bir öğrencinin ülkeye ve dünyaya büyük katkıları olacaktır.” 
açıklaması ile FeTeMM'in öğrenci çıktılarına katkı sağlayacağını ve bu katkının olumlu yönde olacağını ayrıntılı bir şekilde dile getirdiğinden “evet” olarak kodlanmıştır.

Açık uçlu anket cevaplarına göre sekiz FBÖ soruya cevap vermeden boş bırakarak geçtiği için "Hayır” olarak kodlanmıştır. Sekiz FBÖ öğretmeni; FBÖ-4, FBÖ-13, FBÖ-15, FBÖ-16, FBÖ-38, FBÖ-39, FBÖ-43 ve FBÖ-44 FeTeMM'in öğrenci çıktılarına katkısı sorusunu boş bıraktığı için olumsuz, yani “Hayır” olarak kodlanmıştır.

\section{Fen Bilimleri Öğretmenlerinin FeTeMM’i Ölçme ve Değerlendirme Yöntemleri}

Fen Bilimleri öğretmenlerine yönlendirilen açık uçlu anket soruları, yarı yapılandırılmış görüşmeler ve gözlem ile toplanan verilerin analiz edilmesi neticesinde; FBÖ’lerin çoğunluğunun FeTeMM ile ilgili ölçme ve değerlendirmede zorlandıkları tespit edilmiştir. Yeterli olduklarını dile getirerek ölçme ve değerlendirmeye dair açıklamada bulunan öğretmenlerin yapmış oldukları açıklamaların ise yeterlilikleri ile fazla uyuşmadığı görülmektedir. Öğretmenlerin bilgi içeren açık-uçlu sorulara verdikleri cevaplar analiz edilerek FeTeMM ile ilgili ölçme ve değerlendirme kategorisi altında üç seviyeye (yeterli, kısmen yeterli ve yetersiz) göre kodlanmıştır. Bu gruplandırmaya dayalı olarak verilen cevapların yüzde ve frekansları da Tablo 10'da belirtilmiştir.

Tablo 10. Fen bilimleri ögretmenlerinin ölçme ve dĕgerlendirmeleri

\begin{tabular}{|c|c|c|c|c|c|c|}
\hline \multicolumn{7}{|c|}{ Ölçme ve Değerlendirme Kategorisi Kodlar } \\
\hline & $\begin{array}{l}\text { Yeterli } \\
\text { (f) }\end{array}$ & $\%$ & $\begin{array}{l}\text { K1smen } \\
\text { Yeterli } \\
\text { (f) }\end{array}$ & $\%$ & $\begin{array}{l}\text { Yetersiz } \\
\text { (f) }\end{array}$ & $\%$ \\
\hline $\begin{array}{l}\text { Açık Uçlu } \\
\text { Sorulara } \\
\text { göre } \\
\text { öğretmen } \\
\text { Sayıs1 }\end{array}$ & 0 & $\% 0$ & $\begin{array}{c}20 \\
+ \text { FBÖ-33 } \\
+ \text { FBÖ-32 } \\
+ \text { FBÖ-29 }\end{array}$ & $\% 46$ & $\begin{array}{c}25 \\
+ \text { FBÖ-7 } \\
+ \text { FBÖ-34 }\end{array}$ & $\% 54$ \\
\hline $\begin{array}{l}\text { Görüşmeye } \\
\text { alınan } \\
\text { Öğretmen } \\
\text { Sayısı }\end{array}$ & & & $\begin{array}{c}3 \\
\text { (FBÖ-33, } \\
\text { FBÖ-32, } \\
\text { FBÖ-29) }\end{array}$ & & $\begin{array}{c}2 \\
\text { (FBÖ-7, } \\
\text { FBÖ-34) }\end{array}$ & \\
\hline
\end{tabular}

Tablo-10 incelendiğinde, açık uçlu anket sorularında FBÖ’lerin ve görüşme yapılan öğretmenlerin FeTeMM'e dair yeterli ölçme ve değerlendirme yapamadığı görülmüştür.

Bu kategoriye ait diğer bir bulgu ise, açık uçlu anket cevaplarına göre 20 ve görüşme yapılan FBÖ-29, FBÖ-33 ve FBÖ-34 ölçme ve değerlendirme açısından kısmen yeterli olarak kodlanmıştır. Örneğin açık uçlu anket sorularında FBÖ-12 "Potfolyo, Proje değerlendirme 
Raporu, Öz değerlendirme Raporu. ” cevaplarını her ne kadar açıklamamış olsa dahi kavramsal olarak doğru vermiştir. Devamında biçimlendirici değerlendirme için "İzleme testi, quizler, ünite tekrar testleri." cevabını ve özetleyici değerlendirme için “Başarılı, başarısız. ”cevabını vermiştir. Vermiş olduğu cevapları açıklamamış olsa da kavram olarak ve değerlendirme yolu olarak doğru bir şekilde belirtmiştir. Yani FBÖ-12 FeTeMM'i değerlendirme basamağında doğru kavramlar kullanmış olmasına rağmen açıklamalarını yapmamış olduğu için kısmen yeterli kategorisinde dâhil edilmiştir.

Görüşmeye alınan FBÖ-29, FBÖ-32 ve FBÖ-33' de aç1k uçlu sorularda ve görüşmelerde verdikleri cevaplar ile kısmen olarak kodlanmışlardır. FBÖ-32 "Potfolyo değerlendirme, akran

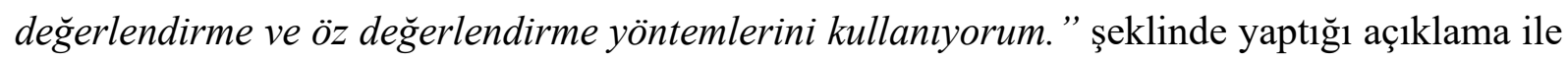
genel olarak FeTeMM değerlendirme basamağında kullandığı yöntemleri belirtmiştir. Biçimlendirici değerlendirme için "formatif testlerdir; yani ünite sonunda değerlendirmelerde kullanıyoruz" açıklamasını yaparken, özetleyici değerlendirme için "Summatif testleri; yani ara sınavlar, sınavlar gibi değerlendirmelerde kullanıyorum." açıklamalarını yapmıştır. Yapmış olduğu açıklamalara ve anket çalışmasına bakarak FBÖ-32'nin biçimlendirici ve özetleyici değerlendirme yöntemlerini bildiği ve fakat FeTeMM disiplinleriyle etegrasyonunu sağlayamadığı belirlenerek kısmen yeterli olarak değerlendirilmiştir.

Son olarak bu kategori altındaki Tablo10'a bakıldığında, açık uçlu ankete cevap veren 25 FBÖ ve görüşmeye alınan FBÖ-34 ile FBÖ-7 ölçme ve değerlendirme yönünden yetersiz olarak kodlanmıştır. FBÖ-3 “Analitik değerlendirme, rubrik. ” cevaplarını vererek herhangi bir açıklamada bulunmamıştır. Devamında biçimlendirici değerlendirme için "Bütün olarak değerlendirme" ve özetleyici değerlendirme için "Belli bir kritere göre değerlendirme" cevaplarını vermiştir. FBÖ-3'ün vermiş olduğu cevaplar kısa ve açıklamasız olduğu için aynı zamanda özetleyici, biçimlendirici değerlendirme yöntemlerini FeTeMM ile alakasız olarak vermiş olduğu için yetersiz kategorisine dâhil edilmiştir.

Görüşmeye alınan FBÖ-34 "Daha çok gösterip yaptırma yöntemini kullanıyorum. Gerek deney olsun gerek maket yapımı olsun gösterdikten sonra kendilerinin yapma firsatı veriyorum. Yaptıkları şeyleri gözlemleyerek doğru ya da yanlış diye dönüt vererek yanlı̧̧ öğrenmeleri düzenliyorum." cevabını vererek daha çok ders içi öğrenmelerden bahsetmiş ve değerlendirme basamağından bahsetmemiştir. FBÖ-34 öğretmene yönlendirilen sorular neticesinde biçimlendirici ve özetleyici değerlendirme olarak kullanmış olduğu değerlendirme 
yöntemleri de cevapsız kalmıştır. Gerek bilgi eksikliği gerekse değerlendirme aşamasına dair bilgi paylaşamamış olduğu için yetersiz olarak kodlanmıştır.

Sınıf ortamında gözlemlenen öğretmenlerin ders içinde değerlendirme yapmak amaçlı soru-cevap yöntemini kullanarak öğrencilere dönüt sağladıkları gözlemlenmiştir. Örneğin; FBÖ-29 8.sınıf öğrencilerine "periyodik tablo" ile ilgili temel kavramaları sözlü yapar gibi "periyot nedir? grup nedir? periyodik cetvelde elementin yerini bulmak için elektron dă̆ılımı nasıl yapılır?" sorularını yöneltmiştir. Yöneltilen sorular tek disiplini ölçen ve FeTeMM ile ilgili kavramsal entegrasyonu içermeyen sorulardır.

\section{Tartışma ve Sonuçlar}

$\mathrm{Bu}$ araştırmanın amacı, FeTeMM'e dair öğretmen görüşlerini alarak öğretmenlerin FeTeMM'i ne ölçüde bildiklerini ve uygulayabildiklerini belirlemektir. FeTeMM ile ilgili olarak; alan bilgisi, anlam (kavramsal bilgi), farkındalık, zorluk, öğretim stratejileri, katkı, ölçme değerlendirme yeterlilikleri bakımından değerlendirilmiştir.

Yapılan bu çalışmada elde edilen bulgulara göre FBÖ’lerin çoğunun FeTeMM'in terimsel olarak ne anlama geldiğini tam olarak bilmedikleri belirlenmiştir. Çalışmaya katılan Fen Bilimleri öğretmenleri FeTeMM'i terimsel olarak biliyor olduklarını söyleseler de yaptıkları açıklamalar genellikle örnek vererek sonuca bağlayamamaktadırlar. FeTeMM'i açıklarken Fen, Teknoloji, Mühendislik ve Matematik disiplinleri arasında bağ kurulmadığ görülmektedir. Bu durumun temel nedeni olarak, elde edilen bulgulardan da görüldüğü gibi öğretmenlerin, popülaritesi gittikçe artan bu yeni öğretim yaklaşımını hem kendilerinin içselleştirememeleri hem de sınıf ortamında uygulayabilecek düzeyde alan ve pedagojik bilgiye sahip olmamalarından kaynaklandığı söylenebilir.

Çalışmanın diğer bir bulgusu ise; açık uçlu anket sorularına göre FBÖ’lerin birçoğunun FeTeMM disiplinlerinin kavramlarını birbirleriyle entegre edebilecek alan bilgisine sahip olmadığıdır. Bu bulgu görüşme ve gözlemlerle desteklenmiştir. Öğretmenlerden bazıları FeTeMM ile ilgili yeterli alan bilgisine sahip olduklarını dile getirseler de sonrasında yapmış oldukları açıklamalar fen bilimlerini diğer alanlara (teknoloji, mühendislik, matematik) entegre edemedikleri için yeterli alan bilgisine sahip olmadıkları belirlenmiştir. Bu bulgular alan yazında yapılan çalışmalarla paralellik göstermektir. Örneğin, Siew, Amir ve Chong (2015) yaptıkları çalışmada FeTeMM'i uygulamak isteyen öğretmenlerin, konuları disiplinler arası ilişki kurarak aktarmakta yeterli alan bilgisine sahip olmadıkları sonucuna ulaşmışlardır. 
Açık uçlu anket çalışması, görüşme ve gözlemler sonucunda öğretmenlerin FeTeMM’e dair farkındalıklarının yüksek olduğu görülmüştür. Fen bilimleri öğretmenleri FeTeMM’i değişen öğretim programına eklenen “mühendislik uygulamaları” ile anlamlandırmış olduklarını ifade etmişlerdir. Öğretmenler FeTeMM'in farkında olsalar da derse nasıl entegre edileceği konusunda fikirlerini tam olarak açıklayamamışlardır. Çalışmanın bulgusu; Bütüner ve Uzun'un (2011) yaptıkları araştırmada da belirttikleri gibi fen öğretmenlerinin, fen ve matematik konuları arasında yeterince bağlantı kuramadıkları bulgusuyla paralellik göstermektedir. Bunun nedeni olarak katılımcıların FeTeMM'e dair farkındalıkları olsa da alan bilgisi eksikliklerinden dolayı disiplinleri bağdaştırarak derse entegre etmekte zorlandıklarından kaynaklandığı söylenebilir. Bununla birlikte, öğretmenlerin FeTeMM eğitimine yönelik yaşadıkları zorlukların nedenleri alan bilgisi eksikliği, teknolojik eksiklikler, materyal eksiklikleri, öğrencilerin derse hazırlıksız gelmeleri gibi nedenlerden kaynaklanabilir. Görüşme yapılan öğretmenler de FeTeMM ile ilgili zorlanma durumlarını aynı nedenlere bağlamaktadırlar. Ders içi gözlem yapılan öğretmenlerin FeTeMM'i ders içinde aktif olarak kullanırken en fazla disiplinler arası entegrasyon kurmakta zorlandıkları ve her disiplini birbirinden bağımsız aktardıkları gözlemlenmiştir. Yapılan bir çalışmada da öğretmenlerin matematik ve fen bilimleri entegrasyonunu sağlayabilirken, teknoloji ve mühendisliği bu alanlara entegre etme konusunda zorlandıkları sonucuna ulaşılmıştır (Delen \& Uzun, 2018).

Öğretmenlerin ders içinde öğretim stratejilerini FeTeMM ile ilişkilendirilerek çağdaş eğitim sistemine uygun olarak kullanamadıkları belirlenmiştir. Öğretmenlerin genel olarak geleneksel yöntemlerle ders anlatımı yaparak tek disiplin ağırlıklı konu işledikleri verilen cevaplardan anlaşılmıştır. Görüşme yapılan öğretmenlerin de alan bilgilerinin eksikliğinden kaynaklı vermiş oldukları öğretim stratejilerini örneklendiremedikleri ve açıklayamadıkları görülmüştür. FeTeMM'in sınıf ortamında etkili bir şekilde kullanılabilmesi için deneysel yöntemlere ağırlık verilmesi gerekmektedir. Jones ve arkadaşları. (2003) sınıf ortamında öğrencilerin yaparak yaşayarak daha geniş çaplı düşünme becerileri elde ettiklerini belirtmektedir. Elde edilen bu bulguların nedeni olarak hem katılımcıların disiplinler arası kavramsal entegrasyon yapabilecekleri alan bilgilerinin eksikliği hem de FeTeMM disiplinlerini birbiriyle entegre etmede kullanabilecekleri çağdaş öğretim yöntemlerini kullanmada yeterli olmadıkları düşünülmektedir.

Açık uçlu anket ve görüşme yapılan öğretmenlerin çok büyük bir çoğunluğu FeTeMM'in öğrenci çıktılarına katkı sağlayacağını ve bu katkının olumlu yönde olacağını 
belirtmiştir. Öğretmenler her ne kadar FeTeMM ile ilgili yeterli alan bilgisine sahip olmasa da ve FeTeMM eğitimini ders içinde disiplinler arası entegrasyon kurarak aktaramasalar da bu eğitimin öğrencilere katkı sağlayacağını söylemişlerdir. FeTeMM'in disiplinlerarası bağ kurularak ele alınmasının öğrencilerin ilgi, tutum, mesleki yönelim gibi özellikleri üzerinde olumlu yönde farklılık oluşturacağı sonucuna ulaşan çalışmalar bulunmaktadır (Christensen ve Knezek, 2017; Gencer, 2015; Guzey \& diğ., 2014; Schmidt \& Kelter, 2017).

Ölçme ve değerlendirme yaparken kullandıkları değerlendirme yöntemlerini açıklayıp örneklendirmesi istenilen öğretmenlerin biçimleyici ve özetleyici değerlendirme yöntemlerini bildikleri fakat bu yöntemleri FeTeMM ile ilişkilendiremedikleri görülmüştür. Görüşmeye alınan öğretmenlerden açıklamış oldukları değerlendirme yöntemlerini FeTeMM'e uyarlayarak örneklendirmeleri istenildiğinde disiplinleri bir arada kullanarak entegre edip örneklendiremedikleri görülmüştür. FeTeMM eğitiminde ölçme değerlendirmenin sürecini ölçmeye odaklı olması gerekmektedir. FeTeMM eğitimine dair yapılan çalışmalarda süreç odaklı değerlendirmeler yapılmalıdır (İdin, 2017). Fakat elde edilen bulgular göstermiştir ki, katılımcıların FeTeMM eğitimine yönelik yeterli alan ve pedagojik bilgilerinin yetersiz oluşu onların FeTeMM eğitimine yönelik beklenen değerlendirme sürecini gerçekleştiremediklerini düşündürmektedir.

\section{Öneriler}

1. Fen Bilimleri öğretmenlerinin FeTeMM ile ilgili alan bilgisi açısından yetersiz oldukları tespit edildiğinden öğretmenleri FeTeMM ile ilgili bilgilendirmek ve sınıf içi uygulamalarına yöneltmek amacıyla hizmet içi eğitim programları düzenlenebilir.

2. Öğretmenler FeTeMM ile ilgili alan bilgileri olsa da uygulama alanları olmadığını dile getirmişlerdir, öğretim ortamları FeTeMM uygulamaları için yeniden yapılandırılabilir.

3. Üniversitelerde öğretmen yetiştirme programlarında FeTeMM eğitimine daha fazla yer verilerek FeTeMM farkındalığı yüksek öğretmenler yetiştirilebilir.

4. Bilimsel alanda yapılan çalışmalarda okul müdürleri hassasiyet göstermemekte ve genellikle yardımcı olmamaktadırlar. Okul müdürleri bilimsel çalışmalar yapan meslektaşlarına yardımcı olarak çalışmalara dâhil olabilir.

5. FeTeMM eğitiminin sınıflarda etkili bir şekilde uygulanabilmesi için öğretmenlerin sahip oldukları farklı disiplinleri birbirleriyle entegre etmedeki alan bilgisi yetersizliğinin giderilmesi için farklı disiplinlerdeki öğretmenlerin iş birliği içerisinde çalışmaları önerilmektedir. 
6. FeTeMM eğitimine yönelik öğretmenlerin alan ve pedagojik olarak geliştirilebilmesi için bu yaklaşıma uygun çevrimiçi (online) ya da yazılı daha fazla örnek uygulamaların geliştirilmesi gerekmektedir.

7. Bu çalışmada beş öğretmenin sınıf içi uygulaması gözlenmiştir. Daha fazla sayıda öğretmenin sınıf içi uygulamaları gözlemlenerek daha detaylı fikirler elde edilebilir.

8. Tüm sınıf düzeylerinde FeTeMM uygulamalarında geleneksel ölçme değerlendirme yöntemleri yerine disiplinler arası entegrasyonu temel alan mühendislik süreçleri içerisinde ürün odaklı üst düzey ölçme değerlendirme yöntemlerinin kullanılması önerilmektedir.

\section{Makalenin Bilimdeki Konumu (Yeri)}

Matematik ve Fen Bilimleri Eğitimi Bölümü/Fen Bilgisi Eğitimi

\section{Makalenin Bilimdeki Özgünlüğü}

Literatürde FeTeMM ile ilgili olarak farklı bakış açılarının temel alındığı çalışmalara rastlanmaktadır. Ancak FeTeMM e dair son yıllarda meydana gelen değişiklikler ve bu konuda aktif olarak görev yapan öğretmenlerin görüşleri ile ilgili yeterli çalışmanın bulunmadığı tespit edilmiştir. Bu nedenle ortaokul fen bilimleri öğretmenlerinin görüşleri; FeTeMM hakimiyeti, alan bilgileri, teknolojik ve pedagojik durumları, kullandıkları öğretim stratejileri, öğrenciye sağladığı katkı ile ilgili görüşleri ve ölçme değerlendirme boyutları incelemeye alınmıştır. 


\section{Kaynaklar}

Akaygun, S. \& Aslan-Tutak, F. (2016). STEM images revealing stem conceptions of preservice chemistry and mathematics teachers. International Journal of Education in Mathematics, Science and Technology, 4(1), 56-71.

Akgündüz, D., Aydeniz, M., Çakmakçı, G., Çavaş, B., Çorlu, M. S., Öner, T. \& Özdemir, S. (2015). STEM eğitimi Türkiye raporu: Günün modası mı yoksa gereksinim mi? A report on STEM Education in Turkey: A provisional agenda or a necessity? White Paper. İstanbul, Turkey: Aydın Üniversitesi.

Akgündüz, D., Ertepınar, H., Ger, A. M., Kaplan Sayı, A. \& Türk, Z. (2015b). STEM eğitimi çalıştay raporu: Türkiye STEM eğitimi üzerine kapsamlı bir değerlendirme. İstanbul Aydın Üniversitesi: STEM Merkezi ve Eğitim Fakültesi.

Aydın, E., \& Delice, A. (2007, November). Experiences of mathematics student teachers in a series of science experiments. Paper presented in the 6th WSEAS International Conference on Education and Educational Technology, Bologna, Italy.

Balc1, A. (2005). Sosyal bilimlerde araştırma. Ankara: Pegema Yayıncılık.

Baran, E., Canbazoğlu Bilici, S., \& Mesutoğlu, C. (2015). Fen, teknoloji, mühendislik ve matematik (FeTeMM) spotu geliştirme etkinliği. Araştırma Temelli Etkinlik Dergisi (ATED), 5(2), 60-69.

Berlin, D. F. \& White, A. L. (1994). The Berlin-White integrated science and mathematics model. School Science and Mathematics, 94(1), 2-4.

Biçer, A., Navruz, B., Capraro, R.M., Capraro, M.M., Öner, A.T. \& Boedeker, P. (2015). STEM schools vs. non-STEM schools: comparing students' mathematics growth rate on highstakes test performance. International Journal on New Trends in Education and Their Implications, 6(1), 138-150.

Bransford, J. D., Brown, A. \& Cocking, R. (2000). How people learn: Mind, brain, experience and school. Washington DC: National Academy Press.

Burrows, A. C., Breiner, J. M., Keiner, J. \& Behm, C. (2014). Biodiesel and integrated STEM: vertical alignment of high school biology/biochemistry and chemistry. Journal of Chemical Education, 91(9), 1379-1389.

Bütüner, S.Ö. \& Uzun, S. (2011). Fen öğretiminde karşılaşılan matematik temelli sıkıntılar: Fen ve teknoloji öğretmenlerinin tecrübelerinden yansımalar. Kuramsal Eğitimbilim Dergisi, 4(2), 262-272. 
Bybee, R.W. (2010). Advancing STEM education: A 2020 vision. Technology and Engineering Teacher, 70(1), 30-35.

Carmel, J. H., Ward, J. S. ve Cooper, M. M. (2017). A glowing recommendation: A Projectbased cooperative laboratory activity to promote use of the scientific and engineering practices. Journal of Chemical Education. 94(5), 626-631. DOI: 10.1021/acs.jchemed.6b00628.

Christensen, R. \& Knezek, G. (2017). Relationship of middle school student STEM interest to career intent. Journal of Education in Science, Environment and Health. 3(1), 1-13.

Çorlu, M., Capraro, R., \& Capraro, M. (2014). Introducing STEM education: Implications for educating our teachers for the age of innovation. Education and Science, 39(171), 7485.

Creswell, J. W. (2007). Qualitative inquiry and research design: Choosing among five approaches (2nd ed.). Thousand Oaks, CA: Sage

Creswell, J. W. (2009). Research design, qualitative, quantitative, and mixed methods approaches. California: SAGE Publications.

Delen, İ. \& Uzun, S. (2018). Matematik öğretmen adaylarının FeTeMM temelli tasarladıkları öğrenme ortamlarının değerlendirilmesi. Hacettepe Üniversitesi Eğitim Fakültesi Dergisi, 33(3), 617-630. DOI:10.16986/HUJE.2018037019.

Doppelt, Y., Mehalik, M. M., Schunn, C. D., Silk, E., \& Krysinski, D. (2008). Engagement and achievements: a case study of design-based learning in a science context. Journal of Technology Education, 19(2), 22-39.

Frankel, J. R., \& Wallen, N. E. (2000). How to design and evaluate research in education. New York: Mc Grawhill, Inc.

Gencer, A. S. (2015). Fen eğitiminde bilim ve mühendislik uygulaması: Furıldak Etkinliğii. Araştırma Temelli Etkinlik Dergisi, 5(1), 1-19.

Guzey, S.S., Harwell, M. \& Moore, T. (2014). Development an instrument to assess attitudes toward science, technology, engineering, and mathematics (STEM). School Science and Mathematics, 114(6), 271-279.

ITEEA Board of Directors. (2009). Proclamation: ITEEA's position on the " $t$ " \& " $e$ " of stem. Retrieved from http://www.iteaconnect.org/AboutITEEA/STEMProclamation.pdf

İdin, Ş. (2017). Örnek ve uygulama destekli fen öğretiminde disiplinler arası beceri etkileşimi. E. Kandemir (Ed.), STEM yaklaşımı ve eğitime yansımaları içinde (s. 255-282). Ankara: Pegem Akademi. 
Jerald, C. D. (2009, July). Defining a 21st century education. Retrieved from http://www.centerforpubliceducation.org/Learn-About/21st-Century/Defining-a21st-CenturyEducation-Full-Report-PDF.pdf

Jones, M.G., Andre, T., Negishi, A., Tretter, T., Kubasko, D., Bokinsky, A., Taylor, R., \& Superfine, R. (March, 2003). Hands-on Science: The impact of haptic experiences on attitudes and concepts.

Knezek, G., Christensen, R., Wood, T.T. \& Periathiruvadi, S. (2013). Impact of environmental power monitoring activities on middle school student perceptions of STEM. Science Education International, 24(1), 98-123.

Levy, F. \& Murnane, R. (2004). The new division of labor: How computers are creating the next job market. Princeton, NJ: Princeton University Press

Marotzki, W. (1995) 'Qualitative Bildungsforschung', in E. König and P. Zedler (eds), Bilanz qualitativer Forschung. Band I: Grundlagen qualitativer Forschung. Weinheim: Deutscher Studien Verlag. pp. 99-134.

MEB (2000). İlköğretim Okulu Fen Bilgisi Dersi Öğretim Programı. Ankara: Milli Eğitim Basımevi.

MEB (2005a). İlköğretim Fen ve Teknoloji Dersi (4 ve 5. Sinıflar) Öğretim Programı. Ankara: Devlet Kitapları Müdürlüğü Basımevi.

MEB (2005b). İlköğretim Fen ve Teknoloji Dersi (6, 7 ve 8. Sinıflar) Öğretim Programı. Ankara: Devlet Kitapları Müdürlüğü Basımevi.

Meyrick, K.M. (2011). How STEM education 1mproves student learning. Meridian K12 School Computer Technologies Journal, 14(1), 1-6.

MEB (2017). Fen bilimleri dersi ögretim programı (3, 4, 5, 6, 7 ve 8. sınıf) tanımı öğretim programı tanitım sunusu. https://tegm.meb.gov.tr/meb_iys_dosyalar/2017_06/09163104_Fen_Bilimleri_Dersi_ YYretim_ProgramY_Karșılaștırmalar.pdf Erişim tarihi: 8.10.2018 tarihinde erişilmiştir.

National Research Council. (2011). Successful K-12 STEM education: Identifying effective approaches in science, technology, engineering, and mathematics. Committee on highly successful science programs for k-12 science education. Board on science education and board on testing and assessment, division of behavioral and social sciences and education. Washington, DC: The National Academies Press. 
PISA (2016). MEB ölçme, değerlendirme ve sınav hizmetleri genel müdürlüğü uluslararası öğrenci değerlendirme programı PISA 2015 Ulusal Raporu.

Sanders, M. E. (2009). Stem, stem education, stemmania. The Technology Teacher, 68(4), 20 26.

Sanders, M. E. (2008). STEM, STEM education, STEM mania. The Technology Teacher, 68(4), 20-26.

Schmidt, K. M. \& Kelter, P. (2017). Science fairs: A qualitative study of their impact on student science inquiry learning and attitudes toward STEM. Science Educator, 25(2), 126132.

Schmidt, W. H. (2011, May). STEM reform: Which way to go? Paper presented at the National Research Council Workshop on Successful STEM Education in K-12 Schools. Retrieved from http://www7.nationalacademies.org/bose/ TEM_Schools_Workshop_Paper_Schmidt.pdf

Siew, N. M., Amir, N., \& Chong, C. L. (2015). The perceptions of pre-service and in-service teachers regarding a project-based STEM approach to teaching science. Springer Plus, $4(8), 1-20$.

Stinson, K., Harkness, S., Meyer, H. \& Stallworth, J. (2009). Mathematics and science integration: Models and characterizations. School Science and Mathematics, 109(3), 153-161, DOI:10.1111/j.1949-8594.2009. tb17951.x

Tezel, Ö. \& Yaman, H. (2017). FeTeMM eğitimine yönelik Türkiye'de yapılan çalışmalardan bir derleme. Ĕ̈itim ve Öğretim Araştırmaları Dergisi, 6(1), 135-145.

Thomasian, J. (2011). Building a science, technology, engineering, and math education agenda. Washington, DC: National Governors Association Center for Best Practices.

Tyson, W., Lee, R., Borman, K. M., \& Hanson, M. A. (2007). Science, technology, engineering, and mathematics (STEM) pathways: High school science and math coursework and postsecondary degree attainment, Journal of Education for Students Placed at Risk, 12(3), 243-270.

Tüysüz, M., Öztürk, G. Geban, O., \& Bektaş, O. (2018). In-service and pre-service science teachers' views regarding conceptual integration of physics, chemistry, and biology disciplines, International Online Journal of Educational Sciences, 10(2), 130-145. DOI: $10.15345 /$ iojes.2018.02.009. 
Wai, J., Lubinski, D. \& Benbow, C. P. (2010). Accomplishment in science, technology, engineering, and mathematics (STEM) and its relation to stem educational dose: a 25year longitudinal study. Journal of Educational Psychology, 102(4), 860-871.

Yıldırım A. \& Şimşek H. (2008). Sosyal bilimlerde nitel araştırma yöntemleri (7. Baskı). Ankara: Seçkin Yayıncılık.

Yıldırım, A. \& Şimşek, H. (2013). Sosyal bilimlerde nitel araştırma yöntemleri. Ankara: Seçkin Yayınc1lik

Yıldırım, B. \& Selvi, M. (2017). STEM uygulamaları ve tam öğrenmenin etkileri üzerine deneysel bir çalışma. Eğitimde Kuram ve Uygulama. 13(2), 183-210.

Yıldırım, B. \& Altun, Y. (2015). STEM eğitim ve mühendislik uygulamalarının fen bilgisi laboratuar dersindeki etkilerinin incelenmesi: El-Cezeri, Journal of Science and Engineering, 2(2), 28-40.

Wagner, T. (2008). Rigor redefined. Educational Leadership, 66(2), 20-24. 


\section{Summary}

\section{Problem Statement}

As a necessity of the present century, the information is thought to be gained by questioning, multi-way thinking, and structuring with our current knowledge. It is among the aims of education curriculums to educate individuals with these skills. The first step to achieve this student profile is to establish an interdisciplinary connection between science and other disciplines. These multidisciplinary approaches are those that are most related to technology, engineering, and mathematics. In recent years, the Science Course Curriculum has been changed to ensure interdisciplinary integration. With these changes, STEM education, which enables the learning of these disciplines in-depth, allows the information learned to be associated with daily life, and has positive effects on 21 st -century life skills, was included in the science curriculum in 2017. The developed and developing countries in the world have rapidly integrated STEM into their education systems. With these changes, teacher education is one of the most crucial prerequisites for using STEM education in accordance with its purpose and providing high level education to students. Thus, they should be able to make interdisciplinary conceptual integration, apply the engineering design process, and use the engineering field with other fields to enable students to learn by designing solutions for daily life problems. However, it is stated in the international and national STEM reports that teachers are not sufficient both in theoretical and pedagogical STEM education. Hence, more studies are needed on the teachers who are in the focus of STEM education. In this context, the aim of the research was to examine science teachers' knowledge and opinions about STEM education. This aspect of the investigation was thought to contribute to the related literature. Within the scope of this goal, the study's problem statement was determined as, "What are the views of science teachers about Science, Technology, Engineering and Mathematics (STEM) education?

\section{Method}

The research was carried out with the phenomenology as the type of qualitative research methods. Moreover, purposeful sampling was used in the study. The sample of the investigation consisted of 50 (28 female and 22 male) voluntary science teachers working in the central districts of Van Province (namely, Tusba, Ipekyolu, and Edremit). The ages of teachers were between 23 and 40, and their professional experience is at least 1 year and at most 15 years. In the research, the data were collected by using an open-ended questionnaire, the semi-structured 
interviews, and classroom observations. First, the questionnaire consisting of seven open-ended questions developed by the researchers was applied to obtain the knowledge and opinions of science teachers regarding STEM education (for example, "What teaching strategies do you use when you structure your teaching environments on the basis of STEM?" and "What does STEM mean to you conceptually? Explain by giving an example?"). After the teachers' answers to open-ended questions were obtained, semi-structured interviews were conducted with five teachers to collect in-depth information. Finally, unstructured observations were made in the classrooms of the interviewed teachers to evaluate the consistency of the data obtained from the interviews with open-ended answers. The analysis of the data was evaluated by content analysis from qualitative analysis methods. In this study, the responses given by the participants regarding STEM were examined under the categories of "Awareness", "Conceptual Knowledge", "Subject Matter Knowledge", "Difficulty”, “Teaching Strategy”, “Contribution”, and "Measurement and Evaluation".

\section{Findings}

When the data collected from science teachers were analyzed, it was determined that $52 \%$ of science teachers knew STEM conceptually. Moreover, science teachers did not have sufficient subject matter knowledge regarding STEM. Although most of the participants were aware of STEM education, they stated that they had difficulty in practicing in their classrooms. This result was also observed that they had difficulties in applying STEM education in the class. Furthermore, it was identified that 84 percent of the participants had a positive effect of STEM on the students' learning concepts in the current study. Especially, it was found that most of the science teachers were not adequate in the use of teaching methods/strategies and the evaluation of their students in STEM education.

\section{Conclusions and Recommendations}

The findings of the study showed that most of the science teachers were not at the desired level to apply STEM education in their classrooms. The two reasons for this situation may be that science teachers did not have sufficient subject matter knowledge to integrate STEM disciplines with each other, and they did not have enough pedagogical knowledge to implement this education. In this context, the recommendations of the study were given below: 
1. Since science teachers were found to be insufficient in terms of subject matter knowledge related to STEM, in-service training programs could be organized to educate teachers about STEM education.

2. Teachers with high STEM awareness should be able to be trained by giving more place to STEM education in universities' teacher education programs.

3. In order to develop teachers' pedagogical content knowledge, more online or written sample applications for STEM education should be developed.

4. In this study, the in-class application of five teachers was observed. More detailed ideas can be obtained by following more teachers' classroom practices. 


\section{EK-1}

\section{FeTeMM Eğitimi ile İlgili Açık Uçlu Öğretmen Soruları}

AÇIKLAMA: Hazırlamış olduğumuz açık uçlu soruların amacı FeTeMM ile ilgili Öğretmen görüşlerini alarak toplamış olduğumuz verileri bilimsel çalışmamızda kullanmaktır. Toplamış olduğumuz verileri kullanırken, öğretmen arkadaşlarımızın özel bilgileri bizde saklı kalacak ve sadece akademik bilgiler paylaşılacaktır.

Ad/ Soyad:

Cinsiyet:

Yaş:

Okul türü:

Okul deneyimi:

1. Yeni Fen Bilimleri öğretim programını incelediniz mi?

a. Öğretim ortamlarının FeTeMM temelinde yapılandırılmasının son yıllarda ortaokul ders kitaplarında 'mühendislik uygulamaları' başlığı altında veriliyor olmasının öğrenci ve ders öğretimi açısından uygun olduğunu düşünüyor musunuz?

b. Sizce öğretim ortamlarının FeTeMM temelinde yapılandırılması fen bilimleri öğretim programına nasil entegre edilmeli?

2. FeTeMM kavramsal olarak sizce ne ifade ediyor? Örnek vererek açıklayınız.

3. Öğretim ortamlarınızı FeTeMM temelinde yapılandırmakta yeterli alan bilgisine sahip olduğunuzu düşünüyor musunuz? Neden?

4. Öğretim ortamlarınızı FeTeMM temelinde yapılandırdığınızda teknolojik ve pedagojik olarak zorluk çekiyor musunuz? Neden?

a. Sizin zorlandığınız durumlar:

b. Öğrencilerin zorlandığ

5. Ögretim ortamlarınızı FeTeMM temelinde yapılandırırken hangi öğretim stratejilerini kullaniyorsunuz?

6. Öğretim ortamlarınızı FeTeMM temelli yapılandırdığınızda öğrenci çıktılarına sizce nasıl bir katkı sağlayacaktır?

7. Öğretim ortamlarınızı FeTeMM temelli yapılandırdığınızda kullandığınız değerlendirme yöntemleri nelerdir?

FeTeMM kavramlarına yönelik aşağıdaki değerlendirme yöntemlerine birer örnek verebilir misiniz?

a) Biçimlendirici Değerlendirme:

b) Özetleyici Değerlendirme: 